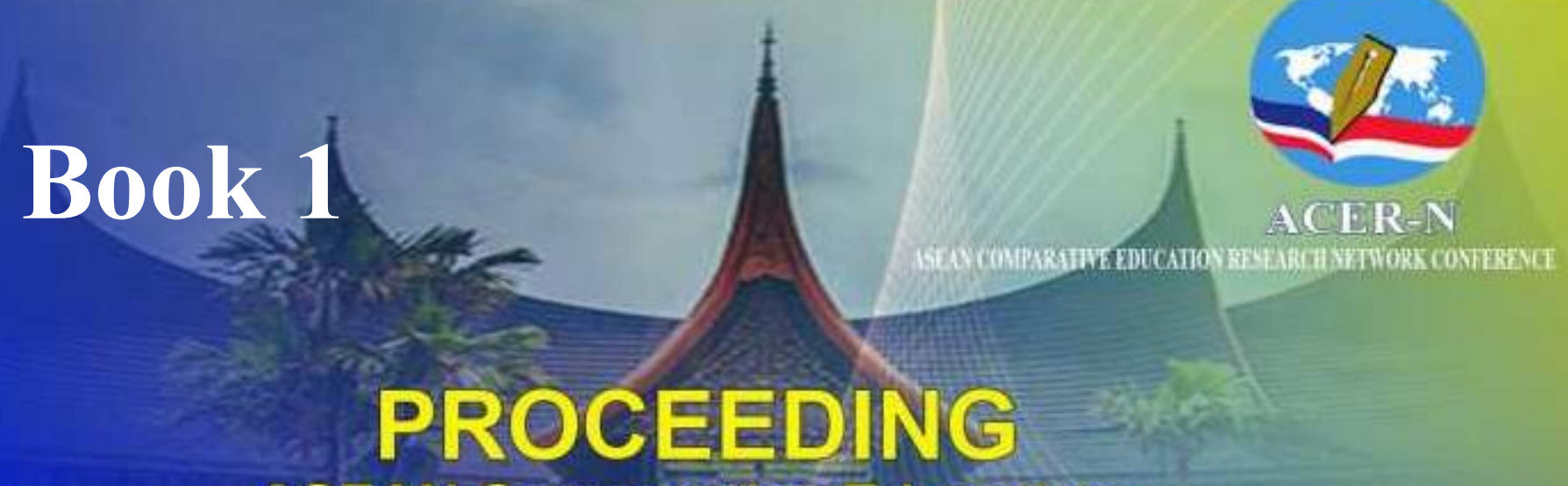

ASEAN Comparative Education

Research Network Conference

[ACER-N 2016]

\title{
The ASEAN Teachers :
}

Towards Standardization of Quality and Qualifications

November $30^{\text {th }}-$ December $01^{\text {st }} 2016$

Grand Inna Muara Hotel Padang, Sumatera Barat, Indonesia

Organized by :

Kopertis Wilayah $\mathrm{X}$

(Sumatera Barat, Riau, Jambi and Kepulauan Riau)

In Collaboration With :

Universitas Negeri Padang

Fakulti Pendidikan Universiti Kebangsaan Malaysia

STKIP PGRI Sumatera Barat

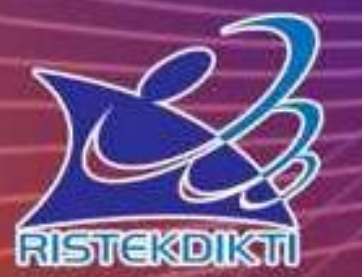

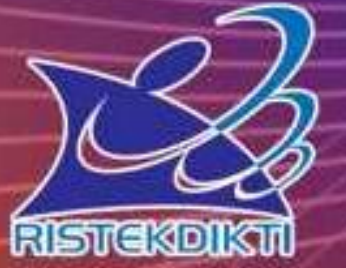
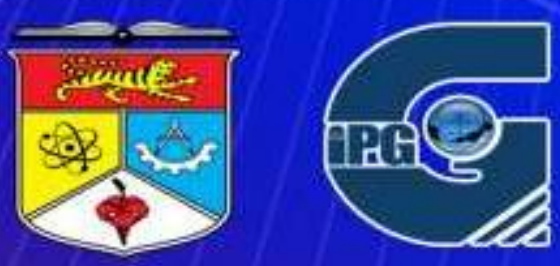

mandirı

syariah 


\section{Proceeding}

\section{ASEAN Comparative Education Research Conference (ACER-N 2016)}

Second Edition 2016

Published by :

(C) Fakulti Pendidikan Universiti Kebangsaan Malaysia

With :

Kopertis Wilayah X (Sumatera Barat, Riau, Jambi dan Kepri)

Universitas Negeri Padang (UNP) Indonesia

STKIP PGRI Sumatera Barat, Indonesia

2016

All rights reserved

It is not allowed to reproduce any part of the article, illustrations and contents of this book in any form and any means either electronic, mechanical, photocopying, recording or other means before getting authority from the Dean of Faculty of Education, UniversitiKebangsaan Malaysia, 43600 UKM Bangi, Selangor, Malaysia

Perpustakaan Negara Malaysia

Pengkatalogan-dalam-Penerbitan

ASEAN Comparative Education Research Conference 2016

Isteti Murni et al. (2016)

Kopertis Wilayah X (Sumatera Barat, Riau, Jambi dan Kepri)

Jalan Khatib Sulaiman No 1 (Gang Mesjid Al Irsyad)

Padang, Sumatra Barat, Indonesia

30 November - 1 Desember 2016

ISBN: 978-983-2267-95-9

Words Designer: Rani Valicia

Typist: Muliyono, Putra Heriadi

Font: Times New Roman, Cambria, Berlin Sans FB, 9,10,11,12 \& 14

Printed by: Kopertis Wilayah X (Sumatera Barat, Riau, Jambi dan Kepri) 


\section{Supported By ACER-N Member Institutions:}

- Fakulti Pendidikan Universiti Kebangsaan Malaysia 43600 Bangi, Sel, DE

- Universitas Pasundan (UNPAS), Bandung, Jawa Barat, Indonesia

- Khonkaen University Thailand Muang District, Muang

- Kolej Universiti Perguruan Ugama Seri Begawan Brunei Darussalam

- Universitas Negeri Padang, Kampus UNP Air Tawar Padang, Indonesia

- STKIP PGRI Sumatera Barat, Jl. Gunung Panggilun, Padang, Indonesia

- Institut Pendidikan Guru Kampus Ilmu Khas, Kuala Lumpur, Malaysia

- IAIN Syekh Nurjati Cirebon Jawa Barat, Jl. Perjuangan By Pass Kota Cirebon Jawa Barat Islamic Institute J1. Sultan Agung Tirtayasa Blok M-2 Cempaka Wangi Regency

- Politeknik Negeri Medan Jl. Almamater No. I Kampus USV Medan

- STAI Al Ma'Arif Ciamis Jl. Umar Soleh - Imbanagara - Ciamis

- STBA YAPARI - ABA Bandung JL. Cihampelas 194 Bandung

- STKIP - YDB Lubuk Alung, Kab Padang Pariaman - Sumatera Barat, Jl. Pasar Mudik No. 91 Lubuk Alung Kab. Padang Pariaman - Sumatera Barat

- Universitas HAMKA - Jakarta, Jl. Tanah Merdeka Pasar Rebo Jakarta Timur

- UIN Sunan Gunung Djati Bandung, JL. Kalijati Indah Raya No.1 Antapani Bandung

- Universitas Ekasakti Padang, Jl. Kali Serayu No. 2C RT 02/RW 08 Lapai Manggalo Padang Sumatera Barat

- Universitas Galuh, JL. R.E. Martadinata No. 150 Ciamis Jawa Barat Indonesia

- Universitas Islam Negeri Bandung, Ciamis

- Universitas Muhammadiyah Tangerang, JL. Perintis Kemerdekaan I/33 Cikokol Kota Tangerang

- Universitas Negeri Yogyakarta, Jongkang Baru Gg. Tawes 172C Sariharjo, Sleman, Yogyakarta

- Universitas Pendidikan Indonesia, Jl. Dr. Setiabudhi 229, Bandung

- Universitas Riau, Jl. Banda Aceh Gg. Kinali No. 38 Pekanbaru

- Universitas Siliwangi, JL. Siliwangi No. 24 Tasikmalaya

- Universitas Negeri Surabaya, Jawa Timur

- Universitas Pasir Pangaraian, Riau

- Universitas Negeri Malang, Jawa Timur

- STIE Haji Agus Salim, Jl. A. Yani No. 79 Bukittinggi Sumatera Barat, Indonesia

- Universitas Muhammadiyah Metro Lampung, Indonesia

- STAIN Sorong Papua Barat 


\title{
EDITORIAL BOARDS
}

\author{
Isteti Murni (Chief Editor) \\ Zusmelia \\ Sri Imelwati \\ Ansofino \\ Nor Aishah Buang \\ Muhammad Yusuf Muhd. Nor \\ AzlinNorhaini Mansor \\ Ismail Haji Raduan \\ Ganefri \\ Asmar Yulastri \\ Ananda Putra \\ Ani Farida \\ Ermanto \\ Ismail Suardi Wekke \\ Syafrimen \\ Radhya Yusri \\ Tika Septia \\ Siskha Handayani \\ Mayuasti
}




\section{PREFACE}

The $4^{\text {th }}$ ASEAN Comparative Education Conference Network (ACER-N) that is hold on November $30^{\text {th }}-$ December $1^{\text {st }} 2016$ has chosen 300 papers that are presented in Inna Muara Hotel Padang, Sumatera Barat Indonesia.

The main purpose of this conference is to provide a forum to cover the participants in discussing and sharing experiences, information, and findings of their researches in education, economic, and culture which are described in the main theme of this conference: " The Asean teacher towards standardization of qualifications ".

This proceeding is published in Compact Disk Form. There are 300 papers which are attached on this proceeding that consists of 242 papers from Indonesian, 56 papers from Malaysian, and 2 papers from Brunei Darussalam. The published papers have been edited by considering the mechanical writing, word choice, and template without changing the contents of the articles.

As the cooperation program in the ASEAN Comparative Research Network (ACER$\mathrm{N}$ ), it is hoped that this proceeding will initiate all researchers in Indonesia, Malaysia, Brunei Darussalam, and other countries around ASEAN to conduct a collaborative research that focuses on issues in improving the quality of education implementation in order to transfer it into the basic of education for world welfare.

My depth appreciations and thanks go to all committee of the proceeding that consist of academic experts from Indonesia, Malaysia for their commitments and contributions that are given in publishing of this proceeding success.

\section{Dr. Isteti Murni, M.EB}

Chief Editor

Kopertis Wilayah X (Sumatera Barat, Riau, Jambi dan Kepri)

STIE Haji Agus Salim Bukittinggi, Sumatera Barat, Indonesia 


\section{TABLE OF CONTENTS}

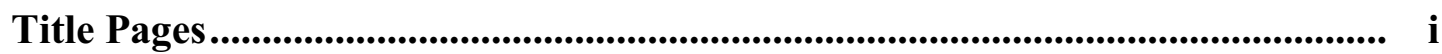

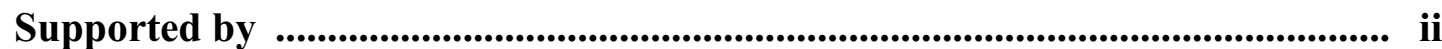

Editorial Boards ............................................................................................................... iii

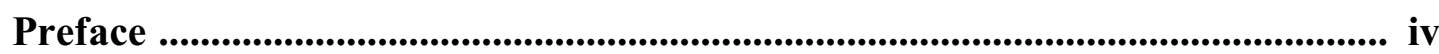

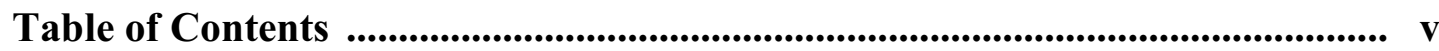

BOOK 1

\begin{tabular}{|c|c|c|c|}
\hline No & Presenter & Title & Pages \\
\hline 1 & Ade Marlia & $\begin{array}{l}\text { THE IMPROVEMENT OF ACTIVITY } \\
\text { AND LEARNING RESULT } \\
\text { THEMATIC BY PROBLEM BASED } \\
\text { LEARNING APPROACH AT SECOND } \\
\text { CLASS } \\
\text { IN ELEMENTARY SCHOOL } 05 \\
\text { BANDAR BUAT PADANG CITY }\end{array}$ & $1-13$ \\
\hline 2 & $\begin{array}{l}\text { Adi Heryadi, Rini Eka } \\
\text { Sari, and Galuh Setia } \\
\text { Winahyu }\end{array}$ & $\begin{array}{l}\text { DEVELOPING ANTI-CORRUPTION } \\
\text { PERCEPTIONS OF ELEMENTARY } \\
\text { SCHOOL STUDENTS THROUGH } \\
\text { ANTI-CORRUPTION TRAINING }\end{array}$ & $14-21$ \\
\hline 3 & Adila Jefiza & $\begin{array}{l}\text { PRE-SERVICE TEACHER } \\
\text { EDUCATION: AN ANALYSIS OF } \\
\text { THE PROBLEMS }\end{array}$ & $22-28$ \\
\hline 4 & Adri Nofrianto, Novyta & $\begin{array}{l}\text { PROBLEM SOLVING: HOW IT CAN } \\
\text { CONTRIBUTE TO STUDENTS } \\
\text { CREATIVITY? }\end{array}$ & $29-37$ \\
\hline 5 & Adzanil Prima Septy & $\begin{array}{l}\text { TOWARD ASEAN TEACHER } \\
\text { STANDARDIZATION, } \\
\text { A LESSON FROM INDONESIA } \\
\text { TEACHER TRAINING AND } \\
\text { CERTIFICATION }\end{array}$ & $38-46$ \\
\hline 6 & Afdaleni & $\begin{array}{l}\text { USING SOCIOAFFECTIVE } \\
\text { LEARNING STRATEGIES } \\
\text { TO IMPROVE STUDENTS' FOREIGN } \\
\text { LANGUAGE ABILITY }\end{array}$ & $47-52$ \\
\hline 7 & $\begin{array}{l}\text { Rahmi, Ainil Mardiyah' } \\
\text { Ratulani Juwita }\end{array}$ & $\begin{array}{l}\text { THE STAGE OF PROTOTYPE } \\
\text { DESIGN ON STUDENTS' } \\
\text { WORKSHEET } \\
\text { ALGEBRA LINEAR ELEMENTARY - } \\
\text { BASED GUIDED DISCOVERY }\end{array}$ & $53-58$ \\
\hline 8 & Alfaiz, Monalisa & $\begin{array}{l}\text { PERCEIVED SELF EFFICACY AS A } \\
\text { PREDICTIVE OF STUDENT } \\
\text { READINESS AND CREATIVITY IN }\end{array}$ & $59-67$ \\
\hline
\end{tabular}

ISBN: 978-983-2267-95-9 


\begin{tabular}{|c|c|c|c|}
\hline & & COLLEGE TASKS & \\
\hline 9 & $\begin{array}{l}\text { Alfattory Rheza } \\
\text { Syahrul, Syailendra Eka } \\
\text { Saputra, Dina Amaluis }\end{array}$ & $\begin{array}{l}\text { ANALISIS FAKTOR-FAKTOR YANG } \\
\text { MEMPENGARUHI MINAT } \\
\text { WISATAWAN MENGUNJUNGI } \\
\text { OBJEK WISATA PANTAI DIKOTA } \\
\text { PADANG }\end{array}$ & $68-89$ \\
\hline 10 & Ali Asmar & $\begin{array}{l}\text { DEVELOPMENT HANDOUT BASED } \\
\text { ON CONSTRUCTIVISM IN THE } \\
\text { LEARNING MATHEMATICAL AT } \\
\text { FIFTH CLASS OF ELEMENTARY } \\
\text { SCHOOL }\end{array}$ & $90-98$ \\
\hline 11 & $\begin{array}{l}\text { Anna Cesaria, Lucky } \\
\text { Heriyanti Jufri, Rosma } \\
\text { Yulian Tary }\end{array}$ & $\begin{array}{l}\text { THE DEVELOPMENT OF } \\
\text { MATHEMATICS STUDENTS } \\
\text { WORKSHEET } \\
\text { BY USING GUIDED DISCOVERY } \\
\text { APPROACH ON MATERIAL OF } \\
\text { RATIONALIZING DENOMITATORS } \\
\text { FRACTIONS SHAPPED ROOT } \\
\text { FOR THE FIRST GRADE STUDENTS } \\
\text { IN SENIOR HIGH SCHOOL } 15 \\
\text { PADANG }\end{array}$ & $99-103$ \\
\hline 12 & $\begin{array}{l}\text { Anna Louis Tan Ling } \\
\text { Ling, Norafzan Marjuki } \\
\text { 'Melor Md Yunus }\end{array}$ & $\begin{array}{l}\text { VOCABULARY ENHANCEMENT } \\
\text { THROUGH VOCKET TO IMPROVE } \\
\text { READINGAND WRITING SKILLS }\end{array}$ & $104-112$ \\
\hline 13 & Anzar Abdullah & $\begin{array}{l}\text { EDUCATION CURRICULUM } \\
\text { LIBERATING AND EDUCATING } \\
\text { (CRITIQUE OF THE NATIONAL } \\
\text { EDUCATION SYSTEM IN } \\
\text { INDONESIA) }\end{array}$ & $113-124$ \\
\hline 14 & Armiati & $\begin{array}{l}\text { CHARACTERISTICS TO ENHANCE } \\
\text { LEARNING CAPABILITIES } \\
\text { MATHEMATICALLY } \\
\text { COMMUNICATION STUDENTS }\end{array}$ & $125-131$ \\
\hline 15 & $\begin{array}{l}\text { Arwizet K, Nizwardi } \\
\text { Jalinus }\end{array}$ & $\begin{array}{l}\text { EFFECT OF COLLABORATIVE } \\
\text { LEARNING MODEL-JIGSAW TYPE } \\
\text { TO MOTIVATION, RESPONSIBILITY } \\
\text { AND LEARNING RESULTS OF } \\
\text { STUDENTS ON THERMODYNAMIC } \\
\text { LEARNING IN VOCATIONAL } \\
\text { EDUCATION }\end{array}$ & $132-142$ \\
\hline 16 & Asmawati, Jasril & $\begin{array}{l}\text { TRAGEDI GERAKAN } 30 \\
\text { SEPTEMBER } 1965 \\
\text { DALAM NOVEL KUBAH DAN } \\
\text { RONGGENG DUKUH PARUK } \\
\text { KARYA AHMAD TOHARI } \\
\end{array}$ & $143-150$ \\
\hline 17 & $\begin{array}{l}\text { Aziah Hassan, } \\
\text { Norhayati Mohd Noor }\end{array}$ & $\begin{array}{l}\text { PERLAKSANAAN PERKHIDMATAN } \\
\text { KAUNSELING KELUARGA DALAM }\end{array}$ & $151-162$ \\
\hline \multicolumn{3}{|c|}{ ISBN: 978-983-2267-95-9 } & vi \\
\hline
\end{tabular}




\begin{tabular}{|c|c|c|c|}
\hline & & $\begin{array}{l}\text { KALANGAN GURU KAUNSELING } \\
\text { SEKOLAH MENENGAH } \\
\text { DI SELANGOR }\end{array}$ & \\
\hline 18 & $\begin{array}{l}\text { Azlie Bin Ibrahim, } \\
\text { Melor Md Yunus }\end{array}$ & $\begin{array}{l}\text { THE USE OF SNAKE AND LADDER } \\
\text { GAME IN IMPROVING ENGLISH } \\
\text { VOCABULARY ACQUISITION IN } \\
\text { RURAL AREA SCHOOL }\end{array}$ & $163-169$ \\
\hline 19 & $\begin{array}{l}\text { Azlin Zainal Abidin, } \\
\text { Azlin Norhaini Mansor }\end{array}$ & $\begin{array}{l}\text { KONSEP KEPIMPINAN EFIKASI } \\
\text { KENDIRI GURU DALAM KONTEKS } \\
\text { MALAYSIA }\end{array}$ & $170-178$ \\
\hline 20 & $\begin{array}{l}\text { Azlina Md Sharif, Nor } \\
\text { Aishah Buang }\end{array}$ & $\begin{array}{l}\text { FAKTOR DORONGAN PEMILIHAN } \\
\text { KERJAYA KEUSAHAWANAN } \\
\text { DALAM KALANGAN SISWAZAH }\end{array}$ & 179-186 \\
\hline 21 & $\begin{array}{l}\text { Basuki, Yulinda Erma } \\
\text { Suryani, Dwi Bambang } \\
\text { Putut Setiadi }\end{array}$ & $\begin{array}{l}\text { TEACHERS' ABILITY IN } \\
\text { DIAGNOSING STUDENTS' } \\
\text { DIFFICULTIESON LEARNING } \\
\text { INDONESIAN }\end{array}$ & 187-192 \\
\hline 22 & Citra Ramayani, Jolianis & $\begin{array}{l}\text { LOCAL REVENUE, EQUALIZATION } \\
\text { FUNDSANDREGIONAL SPENDING } \\
\text { IN SUMATERA BARAT PROVINCE }\end{array}$ & $193-200$ \\
\hline 23 & $\begin{array}{l}\text { Darmairal Rahmad, } \\
\text { Yenita Yatim }\end{array}$ & $\begin{array}{l}\text { THE LEARNING ABILITY OF } \\
\text { STRUCTURAL FUNCTIONAL } \\
\text { THEORY (CASE: 2014TH } \\
\text { STUDDENTS OF THE EDUCATION } \\
\text { PROGRAM OF SOCIOLOGY, STKIP } \\
\text { PGRI SUMATERA BARAT) }\end{array}$ & $201-208$ \\
\hline 24 & $\begin{array}{l}\text { Deltri Apriyeni, Nora } \\
\text { Susanti, Rika Verawati }\end{array}$ & $\begin{array}{l}\text { KEUNTUNGAN AGLOMERASI } \\
\text { DALAM USAHA PETERNAKAN } \\
\text { AYAM RAS PETELUR PADA } \\
\text { KAWASAN SENTRA PRODUKSI } \\
\text { DAN DI LUAR KAWASAN SENTRA } \\
\text { PRODUKSI DI KABUPATEN } 50 \\
\text { KOTA, SUMATERA BARAT }\end{array}$ & $209-223$ \\
\hline 25 & $\begin{array}{l}\text { Desi Areva, Sri } \\
\text { Wahyuni, Ansofino }\end{array}$ & $\begin{array}{l}\text { PENGARUH SUPERVISI KEPALA } \\
\text { SEKOLAH DAN IKLIM KERJA } \\
\text { TERHADAP KINERJA GURU DI SMA } \\
\text { N SE-KECAMATAN PAUH KOTA } \\
\text { PADANG }\end{array}$ & $223-229$ \\
\hline 26 & Desi Rahmatina & $\begin{array}{l}\text { THE RELATIONSHIP BETWEEN } \\
\text { USING ICT AND MATHEMATICS } \\
\text { ACHIEVEMENT : A COMPARISON } \\
\text { OF ASEAN STUDENTS IN TIMSS } \\
2011\end{array}$ & $230-238$ \\
\hline 27 & $\begin{array}{l}\text { Dewi Ariani, } \\
\text { Muhammad Ilyas }\end{array}$ & $\begin{array}{l}\text { THE EFFECT OF CONTEXTUAL } \\
\text { APPROACH TO ACTIVITY AND } \\
\text { STUDENT'S LEARNING OUTCOME } \\
\text { AT EDUCATION RESEARCH } \\
\text { METHODOLOGY SUBJECT } \\
\text { MAJORING EDUCATION OF } \\
\end{array}$ & $239-246$ \\
\hline \multicolumn{3}{|c|}{ ISBN: 978-983-2267-95-9 } & vii \\
\hline
\end{tabular}




\begin{tabular}{|c|c|c|c|}
\hline & & $\begin{array}{l}\text { SOCIAL SCIENCE FKIP UMMY } \\
\text { SOLOK }\end{array}$ & \\
\hline 28 & Dewi Estetikasari & $\begin{array}{l}\text { CAUCHY PROBLEM IN WAVE } \\
\text { EQUATIONFOR ANY DIMENSIONS }\end{array}$ & $247-255$ \\
\hline 29 & $\begin{array}{l}\text { Dian Kurnia Anggreta, } \\
\text { Firdaus, Sri Rahmadani }\end{array}$ & $\begin{array}{l}\text { POTENSI ETOS AGAMA DAN ADAT } \\
\text { SEBAGAI BASIS PEMBERDAYAAN } \\
\text { MASYARAKAT }\end{array}$ & $256-266$ \\
\hline 30 & Edwar Kemal & $\begin{array}{l}\text { A COMPARATIVE STUDY } \\
\text { BETWEEN POLITENESS STRATEGY } \\
\text { AND KATO NAN AMPEK ON } \\
\text { TEACHING AND LEARNING AT } \\
\text { ENGLISH DEPARTMENT STKIP } \\
\text { PGRIWEST SUMATRA FACING } \\
\text { ASEAN ECONOMIC COMMUNITY }\end{array}$ & $267-272$ \\
\hline 31 & Efmi Maiyana & $\begin{array}{l}\text { DESAIN LEARNING MANAGEMENT } \\
\text { SYSTEM (LMS) PADA SMK KOTA } \\
\text { BUKITTINGGI }\end{array}$ & $273-286$ \\
\hline 32 & Efriana Jon & $\begin{array}{l}\text { PERBANDINGAN SKOR } \\
\text { METAKOGNITIF SISWA DALAM } \\
\text { MATA PELAJARAN BIOLOGI DI } \\
\text { SMA } 1 \text { KOTA SUNGAI PENUH } \\
\text { DENGAN MENGGUNAKAN } \\
\text { STRATEGI PEMBELAJARAN } \\
\text { JIGSAW DAN PROBLEM BASED } \\
\text { LEARNING }\end{array}$ & $287-292$ \\
\hline 33 & Elismawati & $\begin{array}{l}\text { IMPROVING MANAGEMENT } \\
\text { STUDENTS' ENGLISH MASTERY } \\
\text { THROUGH NEED ANALYSIS- } \\
\text { BASED MATERIALS } \\
\text { DEVELOPMENT }\end{array}$ & $293-300$ \\
\hline 34 & Elsina Sihombing & $\begin{array}{l}\text { DEVELOPING A MODEL Of } \\
\text { AUTHENTIC ASSESSMENT FOR } \\
\text { ENGLISH TEACHERS AT } \\
\text { SENIOR HIGH SCHOOLS IN } \\
\text { LUBUKLINGGAU }\end{array}$ & $301-320$ \\
\hline 35 & Enyang Sungkawa & $\begin{array}{l}\text { NILAI ETIKA LINGKUNGAN HIDUP } \\
\text { DALAM PIKUKUH MASYARAKAT } \\
\text { BADUY DALAM DI DESA KANEKES } \\
\text { KABUPATEN LEBAK BANTEN }\end{array}$ & $321-324$ \\
\hline 36 & $\begin{array}{l}\text { Erdisna, Liga Mayola' } \\
\text { Vitriani }\end{array}$ & $\begin{array}{l}\text { DATA MINING'S CLUSTERING TO } \\
\text { FIND RAINFALL CHARACTERISTIC } \\
\text { USING K-MEANS ALGORITHM }\end{array}$ & $325-332$ \\
\hline 37 & Eril Syahmaidi & $\begin{array}{l}\text { TRAINING NEEDS ANALYSIS } \\
\text { MODEL INTRUCTION } \\
\text { DEVELOPMENT COMPETENCE } \\
\text { EDUCATION PEDAGOGY } \\
\text { INFORMATICS AND COMPUTER } \\
\text { ENGINEERING }\end{array}$ & $333-342$ \\
\hline
\end{tabular}




\begin{tabular}{|c|c|c|c|}
\hline 38 & Erna Juita & $\begin{array}{l}\text { IMPROVING THE ABILITY OF } \\
\text { STUDENTS IN STATISTICAL DATA } \\
\text { MAPPING METHOD IN SUBJECTS } \\
\text { KULPONSI } \\
\text { CARTOGRAPHICEDUCATION } \\
\text { STUDY PROGRAM IN GEOGRAPHY } \\
\text { STKIP PGRI WEST SUMATERA }\end{array}$ & $343-348$ \\
\hline 39 & Erni & $\begin{array}{l}\text { TUNJUK AJAR MELAYU RIAU } \\
\text { IN SPOKEN TRADITION OF } \\
\text { NYANYI PANJANG } \\
\text { PETALANGAN PEOPLE } \\
\text { PELALAWAN DISTRICTof RIAU } \\
\text { PROVINCE }\end{array}$ & $349-356$ \\
\hline 40 & Estuhono & $\begin{array}{l}\text { IMPROVED STUDENT } \\
\text { PEDAGOGICAL COMPETENCE } \\
\text { THROUGH PEER TEACHING } \\
\text { METHODS ON COURSE } \\
\text { PEDAGOGIC }\end{array}$ & $357-363$ \\
\hline 41 & Fadhilah & $\begin{array}{l}\text { NEEDS ANALYSIS OF } \\
\text { INSTRUCTIONAL MODELS IN THE } \\
\text { COURSE OF APPLIED PHYSICS AT } \\
\text { THE DEPARTMENT OF MINING } \\
\text { ENGINEERING }\end{array}$ & 364-369 \\
\hline 42 & $\begin{array}{l}\text { Fahmi Gunawan, } \\
\text { Suhartini Syukri, Isna } \\
\text { Humaera, Ike Revita }\end{array}$ & $\begin{array}{l}\text { THE INFLUENCE OF CULTURE AND } \\
\text { ETHNISITY ON LECTURERS' } \\
\text { LANGUAGE STYLE TOWARD } \\
\text { HIGHER STUDENTS' } \\
\text { PSYCHOLOGICAL CONDITION IN } \\
\text { INDONESIA }\end{array}$ & $365-374$ \\
\hline 43 & Faishal yasin & $\begin{array}{l}\text { PENDIDIKAN MULTIKULTURAL } \\
\text { DALAM KELUARGA MODREN } \\
\text { (STUDI: KELUARGA DI } \\
\text { KECAMATAN PADANG SELATAN) }\end{array}$ & $375-382$ \\
\hline 44 & Faiza Rini & $\begin{array}{l}\text { TECHNICAL VOCATIONAL } \\
\text { TRAINING (TVET) PRACTICES IN } \\
\text { ASEAN COUNTRIES }\end{array}$ & $383-387$ \\
\hline 45 & Farikah & $\begin{array}{l}\text { DEVELOPING EFFECTIVE } \\
\text { TEACHING THROUGH TP-GW } \\
\text { (THEMATIC PROGRSSION } \\
\text { PATTERNS WITH GALLERY WALK) }\end{array}$ & $388-394$ \\
\hline 46 & Febriyanno Suryana & $\begin{array}{l}\text { REVIEW OF IMPLEMENTATION } \\
\text { TECHNICAL VOCATIONAL AND } \\
\text { EDUCATION TRAINING (TVET) IN } \\
\text { INDONESIA TO FACE OF THE } \\
\text { ASEAN ECONOMIC COMMUNITY } \\
\text { (AEC) }\end{array}$ & $395-402$ \\
\hline 47 & Fenny Purwani & $\begin{array}{l}\text { INTEGRATION OF ICT IN } \\
\text { CURRICULUM DEVELOPMENT: } \\
\text { RESEARCH OVERVIEW }\end{array}$ & $403-413$ \\
\hline
\end{tabular}

ISBN: 978-983-2267-95-9 


\title{
CAUCHY PROBLEM IN WAVE EQUATIONFOR ANY DIMENSIONS
}

\author{
Dewi Estetikasari \\ STKIP PGRI Sumatera Barat \\ Email : estetigue@yahoo.com
}

\begin{abstract}
Formulate problem of Cauchy equation in wave for one-dimensional, two-dimensional, threedimensional and more. Cauchy problem in wave equations to be solved analytically (analytical method), for one-dimensional with coordinate characteristic method, then method of smoothing ball (method of spherical means) is used to solve the problem of Cauchy equation on wave in space-time (three-dimensional), and it is generalized to any odd dimensions which is more and equal to three.
\end{abstract}

Keywords: Wave Equation, Cauchy Problem 


\section{Wave Equation}

A differentialequation isa mathematical equation thatrelatessome function with its derivatives. There are two differential equations, which is ordinary differential equations and partial differential equations. An ordinary differential equations is a differential equation for a function of a single variable, whilea partial differential equation is a differential equation for a function ofseveral variables. An ordinary differential equations contains ordinary derivatives and apartial differential equation contains partial derivatives.

Solving a differential equations means finding an equation with no derivatives that satisfies the given differential equation and it will always involves one or more integration step. Partial differential equations will be obtained a general solution in first performed integrations. To get a particular solution, it will be need boundary conditions (or initial conditions).

The wave equation is a partial differential equation in the form

$$
u(X, t)=c^{2} \Delta u(X, t) \quad \text { for } X \in\left[^{n}\right. \text {. }
$$

$X$ is space variable, andtis time variable,

$u=$ amplitudes of waves as a function of time and position $\quad(m)$

$c=$ wave's velocity in the $x$ direction $\left(\mathrm{ms}^{-1}\right)$.

$\Delta=$ laplace operator.

The Cauchy condition specifies the values of $u$ and several of its normal derivatives, along sone given smooth surface in the coordinate space of all the independent variables (including time). If wave equation $u$ solved at time $t \geq 0$ with the value at the timet $=0, u(X, 0)=\phi(X), u_{t}(X, 0)=$ $\frac{\partial u}{\partial t}(X, 0)=\psi(X)$. This problem is called the Cauchy problem of wave equation. Which is $\phi(X)$ as the initial deflection and $\psi(X)$ as the initial velocity.

The method of Cauchy problem solution in wave equation is different for each dimension of space. The characteristic method has been developed to Cauchy problem solution in wave equation for first-dimensional. The descend method used to solve the Cauchy problem in wave equation for two-dimensional. Method of spherical means is used to solve the Cauchy problem in wave equation for the space-time (three-dimensional) and its generalized to any odd dimensions greater than three.

Integral calculation using the methods above is very long and difficult fatherly solved. The process of integration to find Cauchy problem solution in wave equation requires very high mathematics ability and knowledge. Most introductory books of the partial differential equations do not discuss Cauchy problem even farther, so for students who want to explore this issue will find many difficulty. This article will be formulated Cauchy problem solution in wave equation for onedimensional, two-dimensional, three-dimensional (odd dimensions bigger or equal to three). The method used in this research is descriptive analytical method. Decrease in problem solving is described in detail. The step of this article are study literature on Cauchy problem solution in wave equation and study of literature on methods of progression in solving partial differential equations, and then developed this method for the wave equation Cauchy problem.

\section{Cauchy Problem in Wave Equation}

Generally, the wave equation can be written as

$u_{t t}=c^{2} \Delta u$ atcu $u(x, t)_{t t}=c^{2} \Delta u(x, t)$ for $x \in R^{n}$.

$x$ is a space variable, and

ISBN: 978-983-2267-95-9 
$t$ is a time variable, with

$u=$ amplitudes of waves as a function of time and position ( $m$ )

$c=$ wave's velocity in the $x$ direction $\left(\mathrm{ms}^{-1}\right)$

$\Delta=$ laplace operator

For a one-dimensional wave, $\Delta \frac{\partial^{2}}{\partial x^{2}}$ then $\Delta u=u_{x x}=\frac{\partial^{2} u}{\partial x^{2}}$, for a two-dimensional $\Delta=\frac{\partial^{2}}{\partial x^{2}}+$ $\frac{\partial^{2}}{\partial y^{2}}$ then $\Delta u=u_{x x}+u_{y y}=\frac{\partial^{2} u}{\partial x^{2}}+\frac{\partial^{2}}{\partial y^{2}}$, for three-dimensional $\Delta=\frac{\partial^{2}}{\partial x^{2}}+\frac{\partial^{2}}{\partial y^{2}}+\frac{\partial^{2}}{\partial z^{2}}$, then $\Delta u=$ $u_{x x}+u_{y y}+u_{z z}=\frac{\partial^{2} u}{\partial x^{2}}+\frac{\partial^{2} u}{\partial y^{2}}+\frac{\partial^{2} u}{\partial z^{2}}$, and so on until the n-dimension.

What is meant by the wave equation Cauchy problem is the equation (1) with the following additional requirements, which is boundary condition $\mathrm{u}(0, \mathrm{t})=0, \forall t \in R$, initial condition are initial deflection $\mathrm{u}(\mathrm{x}, 0)=\varnothing(x)$, and initial velocity $u_{t}(x, 0)=\frac{\partial u}{\partial t}(x, 0)=\psi(x)$

Cauchy problem over the wave equation will be solved analytically and settlement method we called the analytic method. The following will describe the Cauchy problem solving wave equation for onedimensional, two-and three-dimensional

\section{Cauchy Problem in Wave Equation for One Dimension}

The dimensions of the wave equation is determined by the spatial dimension of the equation. First, cauchy problem solution in wave equation for one dimensional, for example the variable is $x$. As an illustration, a one-dimensional wave is a wave in the vibration of rope or string.

$u_{t t}=c^{2} u_{x x}$ untuk $-\infty<x<\infty$

By factoring in the differential operator in equation (2), will get:

$u_{t t}-c^{2} u_{x x}=\left(\frac{\partial}{\partial t}-c \frac{\partial}{\partial x}\right)\left(\frac{\partial}{\partial t}+c \frac{\partial}{\partial x}\right) u=0$

To solve an equation (3), initially calculated value $u_{t}+c u_{x}$, suppose it will bev. Then solve the equation $v_{t}-c v_{x}=0$ then we will get a general wave equation solutions, that is

$\mathrm{u}(\mathrm{x}, \mathrm{t})=f(x+c t)+g(x-c t)$

where $f$ and $g$ are arbitrary functions of one variable.

Proof

By operator factor of equation (3),

$v=\left(\frac{\partial}{\partial t}+c \frac{\partial}{\partial x}\right) u=\left(\frac{\partial u}{\partial t}+c \frac{\partial u}{\partial x}\right)=u_{t}+c u_{x}(5 \mathrm{a})$

Then the equation (3) can be written as

$\left(\frac{\partial}{\partial t}-c \frac{\partial}{\partial x}\right) v=\left(\frac{\partial v}{\partial t}-c \frac{\partial v}{\partial x}\right)=v_{t}-c v_{x}=\theta(5 \mathrm{~b})$

Because of that condition will be obtained two first-order equation, which is $v_{t}-c v_{x}=0$ and $u_{t}+c u_{x}=v$. Because the first equation is a homogeneous then the solution is $v(x, t)=\square(x+$ $c t)$, where $\mathrm{h}$ is an arbitrary function. While the second equation is a nonhomogeneous partial differential equation, which has a solution with form $u(x, t)=u+u_{p}$ where $u_{p}$ is particulir solution and $u$ is a solution of the homogeneous equation. Because $v(x, f)=(x+c t)$, then $u_{t}+c u_{x}=\square(x+c t)$, so particulir solution is $u(x, t)=f(x+c t)$. The correlation between the function $f$ and $h$ is

$$
c f^{\prime}(x+c t)+c f^{\prime}(x+c t)=h(x+c t)
$$

or

$$
f^{\prime}(s)=\frac{(s)}{2 c}
$$


the solution of the homogeneous equation is $u(x, t)=g(x-c t)$ with $g$ is an arbitary function. So solution of one-dimensional wave equation (2) is as shown in equation (4)

Another way to get solution is to use the method of coordinate characteristics. Suppose that $\xi=x+c t$ dan $\eta=x-c t$

From those coordinates characteristics will be obtained $\partial_{x}=\partial_{\xi}+\partial_{\eta}$ and $\partial_{t}=c \partial_{\xi}-c \partial_{\eta}$ then $\partial_{t}-\partial_{x}=-2 c \partial_{\eta}$ and $\partial_{t}+c \partial_{x}=2 c \partial_{\xi}$ from equation (3), will get

$\left(\partial_{t}-c \partial_{x}\right)\left(\partial_{t}+c \partial_{x}\right) u=\left(-2 c \partial_{\eta}\right)\left(2 c \partial_{\xi}\right) u=0$

It's mean that $u_{\xi \eta}=0$ with $c \neq 0$. Solution of this equation is

$$
\mathrm{u}=f(\xi)+g(\eta)
$$

For arbitary function of fandg. With subtitution

Will be obtained

$$
\xi=x+c t \eta=x-c t
$$

$$
u(x, t)=f(x+c t)+\mathrm{g}(x-c t)
$$

It is a general solution of the wave equation (because the functions $f$ and $g$ are arbitrary functions). To obtain a special solution of the wave equation must be given two initial conditions. The initial condition for this problem is

$$
u(x, 0)=\phi(x) u_{t}(x, 0)=\frac{\partial u}{\partial t}(x, \theta)=\psi(x)
$$

$\phi(x)$ is called the initial deflection at point $x$ and $\psi(x)$ as the initial velocity at the point $x$, where $\phi$ and $\psi$ are functions that are known. Special solutions for the wave equation Cauchy problem with initial conditions as above is

$$
u(x, t)=\frac{1}{2}[\phi(x+c t)+\phi(x-c t)]+\frac{1}{2 c} \int_{x-c t}^{x+c t} \psi(s) \partial s(7)
$$

Solution forms (7) obtained by subtitut initial conditions (6) to the general solution (4), then for $t=0$, will be obtained

And

$$
\phi(x)=f(x)+g(x)(8)
$$

$$
\psi(x)=c f^{\prime}(x)-c g^{\prime}(x)(9)
$$

Note that (8) and (9) are the two equations for two unknown functions $f$ and $g$. To complete the equation, we change the variable $\mathrm{x}$ with $\mathrm{s}$ for a while. Furthermore differentiation $\mathrm{u}$ to $\mathrm{s}$ at equation (8) and the equation (9) with $\mathrm{c}$ to obtain

$$
\phi^{\prime}=f^{\prime}+g^{\prime} \text { dan } \frac{1}{2} \psi=f^{\prime}-g^{\prime}
$$

By adding and subtracting pairs equation above, it will be obtained

$$
f^{\prime}=\frac{1}{2}\left(\phi^{\prime}+\frac{\psi}{c}\right) \quad \text { dan } \quad g^{\prime}=\frac{1}{2}\left(\phi^{\prime}-\frac{\psi}{c}\right)
$$

Then integratiation both functions above and the result is

And

$$
f(s)=\frac{1}{2} \phi(s)+\frac{1}{2 c} \int_{0}^{s} \psi+A
$$

$$
g(s)=\frac{1}{2} \phi(s)-\frac{1}{2 c} \int_{0}^{s} \psi+B
$$

Where $\mathrm{A}$ and $\mathrm{B}$ is constant. From equation (8), will be obained $A+B=0$. With subtitution $s=x+c t$ into the equation for $f$ and $s=x-c t$ to the equation for $g$ of formula $u(x, t)=$ $f(x+c t)+g(x-c t)$

Then 
or

$$
u(x, t)=\frac{1}{2} \phi(x+c t)+\frac{l}{2 c} \int_{0}^{x+c t} \psi+\frac{1}{2} \phi(x-c t)-\frac{1}{2 c} \int_{0}^{x-c t} \psi
$$

$$
u(x, t)=\frac{1}{2}[\phi(x+c t)+\phi(x-c t)]+\frac{1}{2 c} \int_{x-c t}^{x+c t} \psi(s) \partial s(7)
$$

This formula is solution of the initial value problem or also known as the one-dimensional Cauchy problem in wave equation. Note that $\phi$ should have a continuous second derivative (written $\emptyset \in c^{2}$ ) and $\psi$ have a continuous first derivative $\left(\psi \in c^{1}\right)$, so $u$ have the second partial derivatives are continuous at $\mathrm{x}$ and $\mathrm{t}\left(u \in c^{2}\right)$.

\section{Cauchy Problem Solution in wave equation in space-time}

Consider the wave equation Cauchy problem following three dimensions

$u(x, \theta)=\phi(x) u_{t}(x, \theta)=\frac{\partial u}{\partial t}(x, \theta)=\psi(x)(10)$

$$
u_{t t}=c^{2}\left(u_{x x}+u_{y y}+u_{z z}\right)
$$

solution

$$
u\left(x_{0}, t_{0}\right)=\frac{1}{4 \pi c^{2} t_{0}} \iint_{S} \psi(x) d S+\frac{\partial}{\partial t_{0}}\left[\frac{1}{4 \pi c^{2} t_{0}} \iint_{S} \phi(x) d S\right]
$$

where $S$ is ball with $x_{0}$ center and radius $c t_{0}$. This formula is generally known as Kirchoff formula.

The principle above can be proofed as follows. First will be compared the results of the formula with the principle of cause and effect before getting the formula (11). The value of $u\left(x_{0}, t_{0}\right)$ depends only on the value $\psi(x)$ and $\phi(x)$ for $x$ lies on a spherical surface $S=\left\{\left|x-x_{0}\right|=c t_{0}\right\}$ and not on the value $\psi(x)$ and $\phi(x)$ in the surface of a sphere. This statement can be reversed to declare the value of $\psi$ and $\phi$ at a point connected $x_{1}$ affect only solution on the surface $\left\{\left|x-x_{1}\right|=\right.$ $c t\}$ of cones originating from $\left(x_{1}, 0\right)$. This statement is illustrated in Figure 1 and 2 called Huygens principle. This means any solution of three-dimensional wave equation (eg, electromagnetic signals in empty space right spreads the speed of light c, not faster and not slower.

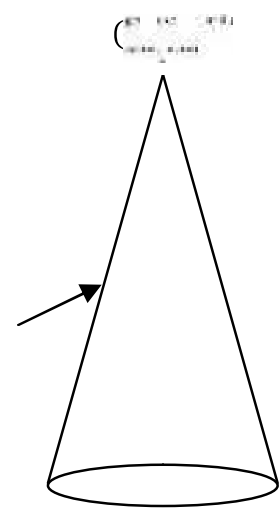

Gambar 1 Ilustrasi S

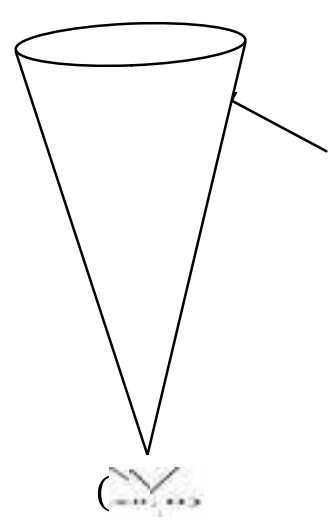

Daerah Pengaruh

(Permukaan

dalam ruang-

waktu)
Gambar 2

Daerah

Pengaruh 
From this principle obtained a clearer picture. It also means each sound that propagates in the air just as fast as the light $c$, no echo, no walls or air is inhomogen. Illustration of this principle is that when we hear a voice at the time $t$, in fact we hear is the sound generated sound sources at the time $t-\frac{d}{c}$, where $\mathrm{d}$ is the distance of the listener from the sound source, and $c$ is the propagation of sound waves (in this principle $c$ is equal to the speed of light).

\section{Proof of Kirchoff's Formula}

In this proof will be used spherical mean method. Suppose the average of $u(\chi, t)$ on the ball $\{|\chi|=r\}$, with center 0 and radius, indicated by $\bar{u}(r, t)$, ie

$\bar{u}(r, t)=\frac{1}{4 \pi r^{2}} \iint_{|x|=r} u(\chi, t) d S$

$=\frac{1}{4 \pi} \int_{0}^{2 \pi} \int_{0}^{\pi} u(x, t) \sin \theta d \theta d \phi(12)$

Where $z, y, z$ expressed in the form of spherical coordinates $r, \theta, \phi$. Now we will see that $\bar{u}$ itself refers to partial equality difernsial

$(\bar{u})_{t t}=c\left(\bar{u}(\bar{u})_{r r}+c^{2} \frac{l}{r}(\bar{u})_{r}\right.$

\section{Bukti}

To facilitate proof, assume $\mathrm{c}=1$. It is known that $(\mathrm{u})=((\mathrm{u}))$, such that

$\Delta(\bar{u})=(\overline{\Delta u})=\left(\overline{u_{t t}}\right)=(\bar{u})_{t t}$

$\Delta \bar{u}=\bar{u}_{r r}+\frac{2}{r} \bar{u}_{r}+$ angular differentiation.

Value $\bar{u}$ which only depends on $r$, while the angular derivative will be equal to zero. Then equation (13) will be proved.

As an alternative proof of (13), will be used theorem divergent for equation $u_{t t}=\Delta u$ with domain $D=\{|\chi| \leq r\}$. Then

$\iiint_{D} u_{t t} d \chi=\iiint_{D} \Delta u d \chi=\iint_{i D} \frac{\partial u}{\partial n} d S$

If converted into spherical coordinates, equation (14) becomes

$\int_{0}^{r} \int_{0}^{2 \pi} \int_{0}^{\pi} u_{t t} \rho^{2} \sin \theta d \theta d \phi d \rho=\int_{0}^{2 \pi} \int_{0}^{\pi} \frac{\partial u}{\partial r} r^{2} \sin \theta d \theta d \phi$

or

$\int_{0}^{r} \bar{u}^{2} \overline{u_{t t}}(\rho, t) d \rho=r^{2} \frac{\partial \bar{u}(r, t)}{\partial r}(15)$

Diferentiation (15) against $\mathrm{r}$, then

$r^{2} \bar{u}_{t t}=\left(r^{2} \bar{u}_{r}\right)_{r}=r^{2} \bar{u}_{r r}+2 r \bar{u}_{r}$

If the equation is divided by $r^{2}$, will be obtained equation (13) with $c=1$

$(\bar{u})_{t t}=(\bar{u})_{r r}+2 \frac{1}{r}(\bar{u})_{r}$

To get formula (11), from

will be obtained

$$
v(r, t)=r \bar{u}(r, t)
$$


$v_{r}=r \bar{u}_{r}+\bar{u}$ dan $v_{r r}=r \bar{u}_{r r}+2 \bar{u}_{r}$

after subtitut to equation (13), then

$v_{t t}=c^{2} v_{r r} \quad(16)$

Equation (16) will be occure if $0 \leq r<\infty$. For $r=0$ function $v=r \bar{u}$ equal to 0

$v(0, t)=0 \quad(r=0)(17)$

This equation will be comply (memenuhi) persamaan awal

$v(r, 0)=r \bar{\phi}(r) v_{r}(r, 0)=r \bar{\psi}(r)(t=0)$

After reduced to one dimensions problem will be obtained partial differential equations (16), the initial conditions (kondisi awal) (17), and the initial conditions (syarat awal) (18). This v problem can be solved whose solution will be given by the following formula:

$v(r, t)=\frac{1}{2 c} \int_{c t-}+\square(\square) \square+-\left[\frac{1}{2} \int_{-\square}+\square(\square) \sqsubset\right]$

for $0 \leq \Pi \leq \square \square$ andanother formula for $\geq \square$.

To get value of $\square$ for $=0$ :

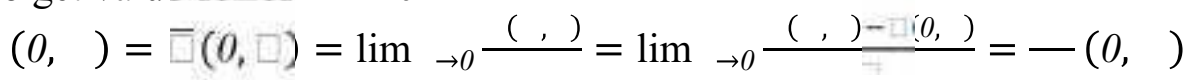

With differentiation (19), will be obtained

$$
-=\frac{1}{2}[(+) \bar{\square}(\square+)+(\square-\square) \bar{\square}(\square \square-)]+\cdots,
$$

Where ... indicates the same correlation that depends on $\bar{\square}$.

When $=0$, then the above statement can be simplified to

$$
[\square](0, \square)=\left(\frac{1}{2 \square}\right)[2 \square \square-(\square \square)]=\quad \square(\square \square) .
$$

This equation will become the solution of equation (20). Such that,

$$
(0, \quad)=\overline{-}(\square \square)=\frac{1}{42} \iint_{\mid} \mid=\quad(\quad) \quad+\cdots \quad(21)
$$

The first statement of formula (11) (in the case correspondent point is origin point and time is denoted by $\mathrm{t}$ ). Time $\mathrm{t}$ multiplied by the average $\psi$ on the ball centered at $\mathrm{t}=0$ and radius ct.

Next we will change the result of (21). If $\mathrm{x} \_0$ an arbitrary point, so

$$
(,)=(+0,) \text {. }
$$

This equation is a solution of the wave equation with initial data $(+0)$ and $(+0)$. Then we can use the results from $(21)$ to $(, \quad)$, to obtain formula

$$
\begin{aligned}
& (0, \quad)=(0, \quad)=\frac{1}{42} \iint_{|=|}[(+0)+\cdots \\
& =\frac{1}{42} \iint_{\mid-\square} \mid=(）+\cdots
\end{aligned}
$$

Formula (22) the first statement (11), the second statement obtained in the same manner. In fact, if we move $\psi$ which was then replaced with $\square$ in the first statement (19) and differentiationover the time $t$, will get a second statement in correspondent with the second statement (11).

\section{Solution of Cauchy Problem in Wave Equation Two Dimensional}

Here it would seem that the Huygens principle is not appropriate for the dimensions of the two. The problem to be solved is

$$
={ }^{2}(+)
$$




$$
\begin{aligned}
& (,, 0)=(,)- \\
& (,, 0)=-(,, 0)=(,)
\end{aligned}
$$

The main idea is to assume $(,, \quad)$ as the solution of three-dimensional problem that does not depend on $z$. The problem can be solved by Kirchhoff formula. For example, it is assumed for the sake of simplification that $=0$ and $(0,0)=(0,0)$. The three-dimensional formula (21) we have the equation:

$$
(0,0, \quad)=\frac{1}{44^{2}} \int_{2^{2}+\square^{2}+2^{2}=\square^{2}-2}(,) \sqcup \sqcup .
$$

The above formula is a formula for the problem (2.3) and (24), but the orm above can still be simplified to two times of integration the top half of the ball $=\sqrt{\square^{2} \square^{2}-2^{2}-{ }^{2}}$. For half of the ball, can be used for surface dS general formula expressed in coordinates $(, \quad)$, consider the following double integral:

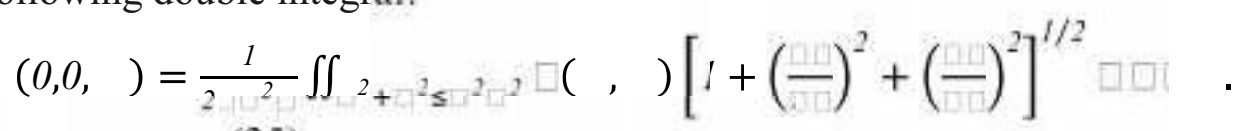

Statement (25) will be the same with:

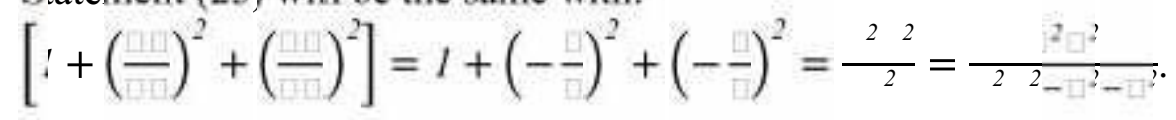

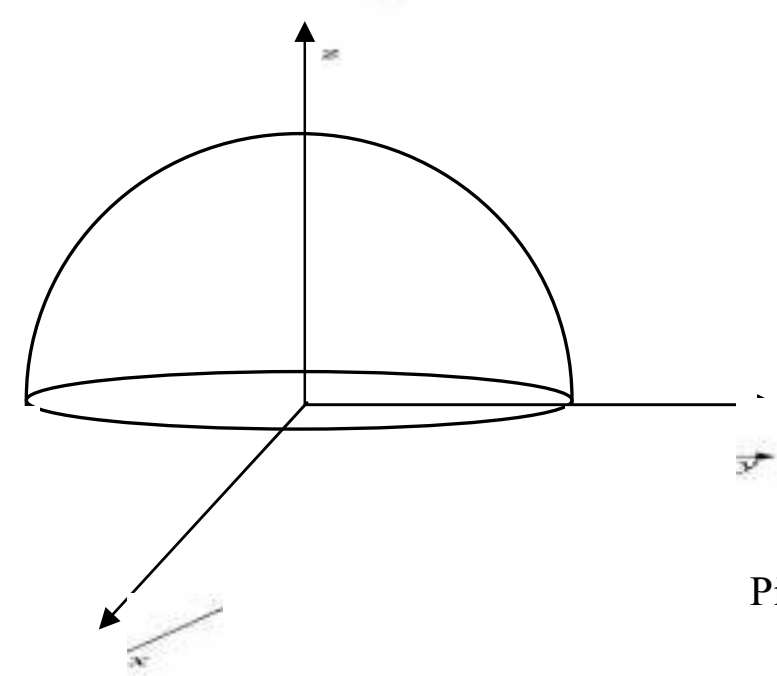

Picture 3 area

Then (25) will be:

$$
(0,0, \quad)=\frac{1}{2} \iiint_{2}+\square^{2} \leq \square^{2}-2 \frac{(\square, D)}{\left(\left(^{2}-\square^{2}-\square^{2}-\square^{2}\right)^{1 / 2}\right.} \frac{}{2}
$$

Equation (26) is formula for $(0,0,7)$. General formula: 


$$
\left(\square 0, \square_{0,}, 0\right)=\iint \frac{(,)}{\left(\square^{2}-v^{2}-\left(\square-\square_{\eta}\right)^{2}-\left(\square-\square_{\theta}\right)^{2}\right)^{1 / 2}} \frac{\square}{2}+-\frac{1}{0}\left[\frac{1}{4 \square^{2}} \iint \quad(\quad)\right]
$$

where $\operatorname{isdisc}\left\{(-0)^{2}-(-0)^{2} \leq{ }^{2} 0^{2}\right\}$.

Formula (27) indicate that $(0,0,0)$ depend on $($,$) and (, \quad)$ on the inside of the cone: $(-0)^{2}-(-0)^{2} \leq 0^{2}$.

This means the Huygens principle does not apply to the two-dimensional. When we throw a pebble into a still pond, the surface waves that form a two-dimensional wave equation approach with a certain speed $c$, where $x$ and $y$ are the horizontal coordinates. Suppose there are water fleas within $\delta$ of a gravel fall wave had suffered at $=/$ and after that will feel the wave propagation. This wavelength will gradually disappear, but theoretically inexhaustible. Physically, when the wavelength gets very small, the wave equation is no longer valid as when other physical effects dominate.

In fact, the method of smoothing the ball can be generalized to any odd dimensions greater than or equal to five. For each dimension odd $(=2+1)$, can be reduced to 2 -dimensional solution to get the formula dimension 2 . From this solution will be shown that the Huygens principle does not apply in the dimensions of 2 .

\section{References}

Boas, MaryL. (1983). Mathematical Methodsin Physical Science. Singapore:John Wiley and Sons, Inc.

Boyce, William E. Prima, Richard C. (2000). Elementary Differential Equations and Boundary Problems. New York:John Wiley and Sons, Inc.

Ratubagus, Ade Prima. (2000). Pengaruh Gaya Gesekan dan Gaya Elastis pada Solusi Persamaan Gelombang Kasus Ujung Bebas dengan Separasi Variabel. Bandung: Matematika ITB.

Strauss, Walter A. (1992). Partial Differential Equation: An Introduction. New York:John Wiley and Sons, Inc.

Yngvason, Jacob. (1995). Waves and Distribution. Singapore: World Scientific Publishing Co. Pre. Ltd. 


\title{
POTENSI ETOS AGAMA DAN ADAT SEBAGAI BASIS PEMBERDAYAAN MASYARAKAT
}

\author{
Dian Kurnia Anggreta ${ }^{1}$ Firdaus $^{2}$, Sri Rahmadani ${ }^{3}$ \\ ${ }^{1,2,3}$ Pendidikan Sosiologi STKIPPGRI Sumatera Barat, Indonesia \\ Email: anggreta14@gmail.com
}

\begin{abstract}
Abstrak
Tulisan ini membahas tentang potensi adat dan agama yang dapat digunakan dalam kegiatan pemberdayaan masyarakat. Gagasan ini dilatarbelakangi oleh pelaksanaan kegiatan pembangunan kerap menempatkan masyarakat sebagai obyek, bukan sebagai subyek. Hal ini menyebabkan masyarakat menjadi pasif dan pelibatannya hanya sebagai pelaksana kegiatan. Padahal, secara naluriah masyarakat memiliki keyakinan (Agama) dan adat istiadat yang dapat digunakan sebagai sumber spirit dalam kegiatan pemberdayaan. Potensi tersebut dalam tulisan ini disebut sebagai etos adat dan agama, yaitu semangat yang didorong oleh faktor keyakinan (Agama) dan adat yang dijadikan sebagai sumber nilai dalam menjalankan kehidupan. Etos ini, dalam pandangan penulis dapat digunakan sebagai spirit awal dalam pemberdayaan ekonomi. Hasil akhirnya diharapkan mampu meningkatkan kesejahteraan masyarakat. Artikel ini ditulis berdasarkan studi literatur dari berbagai sumber seperti buku, jurnal, artikel, makalah dan media cetak dan online. Hasil studi menunjukkan bahwa etos adat dan Agama dimiliki oleh setiap masyarakat dan memiliki potensi yang besar untuk digunakan dalam kegiatan pemberdayaan.
\end{abstract}

Kata Kunci: Pemberdayaan Masyarakat, Potensi Agama dan Adat, Etos Adat dan Agama 


\section{Latar Belakang}

Perubahan ke arah perbaikan dalam penyelenggaraan ekonomi kerakyatan yang lebih berkeadilan, merata dan lebih berorientasi kepada masyarakat, merupakan sebuah keharusan dalam penataan ekonomi mikro kerakyatan, yang bergerak di sektor informal. Reformasi ekonomi di Indonesia perlu ditegaskan dengan adanya pendekatan pengembangan eknomi mikro yang lebih berorintasi kepada masyarakat. Tujuannya agar proses pemberdayaan ekonomi menjadi milik masyarakat. Sehingga format ekonomi kerakyatan lebih mengacu pada konsepsi-konsepsi masyarakat, terhadap pemberdayaan ekonomi dimana masyarakat tidak hanya menjadi obyek ekonomi makro.

Ekonomi kerakyatan yang menempatkan masyarakat pada level pertama semakin penting, mengingat kekuatan ekonomi masyarakat Indonesia lebih dominan bergerak pada sektor informal. Hal tersebut dibuktikan bahwa ekonomi sektor informal lebih mampu untuk bertahan saat krisis ekonomi yang terjadi pada pertengahan 2007 lalu yang berkelanjutan hingga sekarang. Selain catatan kegagalan pelaku ekonomi makro yang harus gulung tikar karena tidak mampu bertahan di tengah pertarungan ekonomi yang semakin ketat, ekonomi informal tetap eksis merupaan aspek lain yang memperkuat argumen bahwa ekonomi informallah sebenarnya yang memperkuat perekonomian negara secara tidak langsung.

Perubahan pokok yang ada pada paradigma baru pemberdayan ekonomi dimaksud disini adalah pemberian peran yang lebih besar kepada masyarakat dan menempatkannya sebagai subyek sekaligus obyek ekonomi. Hubungan fungsional antara para pelaku ekonomi dan obyek ekonomi yang ada selama ini mengalami modifikasi sesuai dengan kondisi, peluang, tujuan dan tuntutan yang berkembang di masyarakat. Tentu semuanya didasarkan pada kapasitas dan norma yang dianut oleh masing-masing pelaku ekonomi. Atau oleh Chambers disebut sebagai pola pemberdayaan masyarakat yang merangkum nilai-nilai sosial dan mencerminkan people centerd, participatory, empowering dan sustainable(Chamber 1987). Nilai sosial masyarakat dalam tulisan ini disebut sebagai potensi yang dimiliki masyarakat, berupa etos agama dan adat.

Etos agama dan adat terdapat dalam masyarakat, mampu menggerakkan masyarakat. Kita dapat mengambil contoh pada aksi damai 4 November 2016, puluhan ribu demonstran dari berbagai daerah di Indonesia berkumpul di Jakarta, menyampaikan aspirasi menuntut penuntasan proses hukum calon Gubernur Jakarta Basuki Tjahaja Purnama (Ahok) atas dugaan penistaan Agama (CNNIndonesia 2016). Terlepas dari berbagai kontroversi yang muncul seputar aksi damai tersebut, seperti benar atau tidaknya terjadi penistaan Agama, demonstrasi ditunggangi oleh berbagai pihak berkepentingan dan lain sebagainya. Mayoritas yang menggerakkan individu-individu dan ormas dari berbagai daerah di Indonesia adalah nilai Agama yang telah ditanamkan melalui proses sosialisasi, untuk membela Agama. Tentu masih banyak etos agama dan adat yang terdapat dalam masyarakat, serta dapat digunakan dalam kegiatan pemberdayaan, dengan tujuan tercapai kesejahteraan. Berdasarkan pertimbangan itulah tulisan ini berupaya mengulas potensi yang dimiliki masyarakat, yang dapat digunakan dalam kegiatan pemberdayaan ekonomi.

\section{Tujuan dan Objektif Kajian}

ISBN: 978-983-2267-95-9 
Berdasarkan pemaparan dalam latar belakang diatas, tulisan ini bertujuan untuk: Mendeskripsikan potensi agama dan adat yang dapat digunakan dalam kegiatan pemberdayaan masyarakat.

Kajian pemberdayaan masyarakat, memanfaatkan potensi yang dimiliki masyarakat telah banyak dilakukan. Seperti penelitian yang dilakukan Damayanti, et.al, dengan judul Strategi Capacity Building Pemerintah Desa dalam Pengembangan Potensi Kampoeng Ekowisata Berbasis Masyarakat Lokal. Potensi yang dimiliki masyarakat dalam tulisan ini adalah Sumber Daya Alam dan tradisi adat istiadat masyarakat yang dikembangkan menjadi Kampoeng Ekonwisata. Capacity Building yang digagas pemerintah desa adalah dengan meningkatkan Sumber Daya Manusia, seperti memberikan pelatihan-pelatihan (Damayanti, Soeaidy, and Ribawanto 2014).

Tulisan yang juga membahas etos yang dimiliki masyarakat, ditulis oleh Nadjib, dalam tulisannya yang berjudul Agama, Etika dan Etos Kerja dalam Aktivitas Ekonomi Masyarakat Nelayan Jawa. Dalam tulisan ini diulas Nelayan Jawa mayoritas beragama Islam, masih melaksanakan praktik religi yang diwariskan nenek moyang seperti ritual sedekah laut, sesaji dan santet. Namun nelayan masuk dalam kelompok masyarakat miskin ini, rata-rata memiliki etos kerja tinggi. Ditemukan longgarnya pemahaman atas nilai Agama dan tatanan etika yang dianut masyarakat membentuk sifat dan karakter nelayan cenderung pesimis, foya-foya dan boros (Nadjib 2013). Tulisan Nadjib lebih fokus kepada penyebab kemiskinan nelayan, walaupun sama-sama membahas Agama dan etos yang dimiliki oleh masyarakat. Namun dalam tulisannya najib menyatakan Agama tidak mampu mendorong masyarakat agar berperilaku hemat, disiplin, menjauhi perilaku konsumtif, karena longgarnya pemahaman Agama.

\section{Metodologi}

Tulisan ini menggunakan metode studi literatur. Literatur yang dikumpulkan diantaranya buku, jurnal, artikel, makalah dan informasi media cetak dan online. Literatur yang terlah dikumpulkan dipelajari, agar menjadi lebih fokus, etos Agama yang dibahas terkait Etika Protestan dan etos dalam Agama Islam. Sedangkan etos adat dikumpulkan adalah etos adat masyarakat suku bangsa Minangkabau dan etos yang dimiliki perempuan di Bangladesh dalam program Grameen Bank. Disamping itu tentu dikumpulkan literatur seputar pemberdayaan masyarakat.

Meskipun dua tulisan diatas sama-sama membahas pemberdayaan masyarakat dengan mengidentifikasi potensi yang dimiliki masyarakat, namun secara spesifik potensi yang diulas dalam tulisan ini adalah etos agama dan adat yang dimiliki masyarakat. Etos agama dan adat yang akan diuraikan dalam tulisan ini belum dibahas dalam tulisan terdahulu.

\section{Pemberdayaan Ekonomi Masyarakat}

Pemberdayan secara harfiah dapat dinyatakan sebagai proses, cara, perbuatan memberdayakan. Pemberdayaan masyarakat dapat didefinikan sebagai upaya meningkatkan kemampuan dan potensi yang dimiliki masyarakat sehingga dapat mewujudkan jati diri, harkat dan martabatnya secara maksimal untuk bertahan dan megembangkan diri secara mandiri baik dibidang ekonomi, sosial agama dan budaya (Damayanti et al. 2014). Selain itu pemberdayaan menurut Korten (1993) mengandung arti memberi peran kepada lapisan bawah dalam proses perencanaan, pelaksanaan dan pengawasan pembangunan (Suherman 2004). Pada prinsipnya program-program pemberdayaan ekonomi rakyat yang benar adalah sejauh mungkin 
mengurangi "intervensi" pemerintah dan aparat pemerintah, dan sebanyak mungkin melibatkan partisipasi masyarakat sejak dari perencanaan program sampai pelaksanaan dan pemanfaatan program (Soemardjan 2000). Jadi pemberdayaan ekonomi masyarakat dalam tulisan ini didefinisikan sebagai upaya meningkatkan kemampuan dan potensi ekonomi masyarakat agar tercapai kesejahteraan (welfare) melalui potensi yang mereka miliki.

Kesejahteraan sendiri merupakan konsep yang selalu dikaitkan dengan materia. Karena saat membahas tingkat kesejahteraan seseorang, hampir selalu dihitung dari jumlah pendapatan tertentu, baik dalam bentuk uang tunai, barang atau jasa (Sherraden 2006). Indikator yang pasti tentang kesejahteraan memang sulit ditetapkan. Hal ini tentu berbeda dalam menentukan indikator kemiskinan. Banyak studi yang membahas tentang Indikator kemiskinan, seperti Sayogyo mengkasifikasikan tipe orang miskin menjadi miskin (poor), sangat miskin (very poor), dan termiskin (poorest), menggunakan indikator penghasilan yang diwujudkan dalam bentuk beras dengan jumlah tertentu dianggap cukup memenuhi kebutuhan makan minum. Sebagai contoh tipe miskin (poor), merupakan orang yang berpenghasilan kalau diwujudkan dalam bentuk beras yakni $320 \mathrm{~kg} /$ orang/tahun. Jumlah ini dianggap cukup memenuhi kebutuhan makan minimun (1900 kalori/orang/hari dan 40gr protein/orang/perhari) (Suyanto 1995). Jika kita gunakan harga beras kualitas menengah saat ini Rp 12.000/kg, makan orang yang berpendapatan Rp3.840.000/orang/tahun (Rp 320.000/orang/bulan) masuk dalam kategori miskin. BPS menetapkan 14 indikator kemiskinan, seperti:

1. Luas lantai bangunan tempat tinggal kurang dari $8 \mathrm{~m}^{2}$

2. Jenis lantai tempat tinggal terbuat dari tanah/ bambu/ kayu murah

3. Jenis dinding tempat tinggal dari bambu/ rumbia/ kayu berkualitas rendah/ tembok tanpa dipleter

4. Tidak memiliki fasilitas buang air besar/ bersama-sama dengan rumah tangga lain

5. Sumber penerangan rumah tidak menggunakan listrik

6. Sumber air minum berasal dari sumur/ mata air tidak terlindung/ sungai/ air hujan

7. Bahan bakar untuk memasak sehari-hari adalah kayu bakar/ arang/ minyak tanah

8. Hanya mengkonsumsi daging/ susu/ ayam dalam satu kali seminggu

9. Hanya membeli satu stel pakaian baru dalam setahun

10. Hanya sanggup makan sebanyak satu/ dua kali dalam sehari

11. Tidak sanggup membayar biaya pengobatan di puskesmas/ poliklinik

12. Sumber penghasilan kepala rumah tangga adalah petani dengan luas lahan $500 \mathrm{~m}^{2}$, buruh tani, belayan, buruh bangunan, buruh perkebunan dan atau pekerjaan lainnya dengan pendapatan dibawah Rp 600.000 per bulan

13. Pendidikan tertinggi kepala rumah tangga: tidak sekolah/ tidak tamat $\mathrm{SD} /$ tamat $\mathrm{SD}$

14. Tidak memiliki tabungan/ barang yang mudah dijual dengan minimal Rp500.000, seperti sepeda motor kredit/ non kredit, emas, ternak, kapal motor atau barang modal lainnya.

Jika suatu keluarga memenuhi minimal 9 indikator, maka dapat dikategorikan miskin. Dan berdasarkan Laporan Bulanan Data Sosial Ekonomi Indonesia edisi 48, jumlah penduduk miskin pada Sepetember 2013 sebanyak 28,55 juta orang (11,47\%) (BPS 2014). Seluruh indikator tidak terpenuhi atau memiliki kemampuan memenuhi kebutuhan dasar, dapat dikatakan bukan terkategori miskin. Saat kesejahteraan (welfare) dinyatakan sebagai terpenuhi kebutuhan dasar seperti yang diunggapkan BPS, masyarakat yang sejahtera merupakan masyarakat yang tidak memiliki 14 indikator diatas. 
Kembali ke pembahasan pemberdayaan, persoalan umum terjadi dalam pembedayaan ekonomi yang berorentasi pada masyarakat adalah rumusan kebijakan ekonomi yang bersifat top-down, dan sering bersifat makro. Hal tersebut menempatkan masyarakat sebagai obyek kebijakan dan sekaligus obyek ekonomi. Masalah komunikasi antara masyarakat dengan pihak pemerintah sebagai pihak yang menentukan distribusi sumberdaya ekonomi menjadi kendala lain ketika sektor ekonomi informal yang menjadi kekuatan rakyat tidak mampu menjadi tolak ukur dalam melahirkan kebijakan. Selain itu kemampuan dan keberanian mengartikulasikan kekuatan ekonomi dan aspirasi merupakan kendala umum yang dimiliki banyak masyarakat. Disamping itu juga kemampuan untuk memodifikasi berbagai mekanisme ekonomi yang umum berlaku, serta disadari atau tidak pemerintah dan swasta yang memiliki kepentinggan, dan enggan melepaskan sebagaian kepentingan mereka.

Agar dapat berjalan, pemberdayaan ekonomi idealnya menempatkan masyarakat sebagai tolak ukur utama. Masyarakat memiliki peran dalam menentukan ukuran, kriteria dan mekanisme pemberdayaan ekonomi yang dilakukan sesuai dengan potensi yang mereka miliki. Namun mekanisme untuk menentukan kebijakan pemberdayaan yang dapat menampung aspirasi semua masyarakat bukanlah hal yang sederhana. Tingkat pendidikan dan sumber daya yang dimiliki akan mempengaruhi bentuk sektor ekonomi yang akan menjadi pilihan dalam rangka meningkatkan taraf hidup yang lebih layak atau meningkatkan kesejahteraan.

Saat perumusan kebijakan diserahkan sepenuhnya kepada masyarakat sebagai subyek ekonomi, untuk meningkatkan taraf hidup yang lebih layak (kesejahteraan), dan tentunya diperlukan penguatan Sumber Daya Manusia (capacity building). Hal ini diperlukan karena pengetahuan berbanding lurus dengan tingkat keberhasilan suatu program. Pemberdayaan ekonomi terhadap masyarakat ini, dilakukan dalam upaya memberikan penguatan secara partisipatif kepada masyarakat dalam menentukan bentuk dan tujuan sektor ekonomi yang mereka inginkan, sesuai dengan kapasitas dan tingkat sumber daya masing-masing. Disini ruang dan kesempatan bagi masyarakat untuk terlibat di setiap tahap dan tingkat ekonomi cukup terbuka, namun untuk dapat berperan sebagai pelaku utama dalam sektor ekonomi, bukanlah hal yang sederhana bagi masyarakat tanpa proses penguatan kapasitas di level individu. Maka untuk itu dibutuhkan pemberdayaan ekonomi dengan memanfaatkan etos Agama dan adat. Untuk definisi etos yang dirujuk dari tulisan Tasmara dalam Nadjib merupakan sikap, kepribadian, karakter serta keyakinan yang dimiliki seseorang atau masyarakat yang terbentuk oleh berbagai kebiasaan, pengaruh budaya, serta sistem nilai yang diyakininya (Nadjib 2013).

\section{Agama dan Adat sebagai Etos yang Universal}

Dalam literatur antropologi, agama dan adat merupakan bagian dari kebudayaan. Masyarakat dengan kebudayaan merupakan aspek yang tidak dapat dipisahkan. Kebudayaan menunjuk kepada berbagai aspek kehidupan, meliputi cara-cara berlaku, kepercayaankepercayaan, sikap-sikap dan hasil dari kegiatan manusia yang khas untuk suatu masyarakat atau kelompok penduduk tertentu (Ember et al. 1996). Terdapat 7 unsur kebudayaan yang universal seperti: Bahasa, Sistem religi, sistem pengetahuan, sistem peralatan dan perlenggapan hidup, mata pencarian, sistem kemasyarakatan dan kesenian. Agama yang dikategorikan sebagai sistem religi merupakan unsur kebudayaan yang sangat esensial dalam masyarakat karena unsur kebudayaan yang sulit berubah. Dalam istilah lain agama juga disebut dengan cultural core. Sebagai inti kebudayaan, agama kemudian menjadi sistem nilai budaya, 
pandangan hidup dan ideology dalam kehidupan masyarakat. Sistem nilai budaya tersebut merupakan tingkat yang paling tinggi dan paling abstrak dari adat-istiadat. Nilai-nilai budaya memberikan pedoman kepada manusia dalam menentukan arah dan orientasi hidup. Nilai budaya juga memberi pedoman bagi manusia dalam menentukan norma-norma atau aturanaturan yang menjadi acuan dalam kehidupan mereka. Norma-norma yang berlaku dalam masyarakat tersebut kemudian disebut dengan istilah adat-istiadat (Koentjaraningrat 1981).

Agama dan adat dalam kehidupan sehari-hari kemudian menjai ciri dan identitas setiap suku bangsa yang ditanamkan kepada setiap individu dalam masyarakat. Proses penanaman nilai-nilai Agama dan adat dalam masyarakat sudah dimulai saat seorang individu baru dilahirkan. Kondisi ini berlanjut sepanjang hidup individu. Nilai agama dan adat tersebut akan terinternalisasi dalam diri individu, sehingga mempengaruhi nilai dan norma yang dianut dan mempengahuri cara bertindak individu. Sebagai sebuah kebudayaan, nilai agama dapat menjadi penghalang proses perekonomian, jika bertentangan dengan Agama. Begitu pula sebaliknya, nilai agama dapat menjadi pendorong perekonomian, saat tidak bertentangan dengan Agama. Seperti dalam Etika Protestan dan Etos kerja dalam Islam.

Sebagai etos, orang Madura perantau telah menjadikan agama dan kearifan lokal (adat) sebagai motivasi etos bisnis di kota Malang. Motivasi mereka dalam bekerja lebih disebabkan karena dua faktor yaitu agama dan adat. Secara agama, mereka berpandangan bahwa bekerja merupakan bagian dari ibadah kepada Tuhan. Secara adat dalam tradisi Madura, setiap orang Madura Madura harus bekerja keras (nyare engon) untu diri dan keluarganya. Jika tidak, masyarakat akan menstigma sebagai pemalas (atonggul to'ot), tidak cakap (ta' brenteng ta' pettel, ta' bilet) dan kata-kata lain yang bisa menurunkan rasa harga diri (Djakfar 2011).

Bahkan gerakan penolakan terhadap pembangunan pabrik semen di Sukolilo, Pati Jawa Tengah oleh masyarakat Samin di Pati Jawa Tengah, didorong oleh etos agama, prinsip hidup yang diwariskan dari nenek moyang mereka. Gerakan kaum Samin aktif menyuarakan aspirasinya dengan ekspresi kultural yaitu: (1) keteguhan sikap menolak eksploitasi alam, (2) perlawanan terhadap represi kekuasaan dengan politik ingatan untuk membentuk kesatuan komunal, dan (3) transformasi pengetahuan dan kebudayaan melalui sistem "pondok pasina'on". Dari pondok pasionaon inilah, nilai-nilai moral dan etika sedulur sikep, diwariskan kepada generasi mudanya, termasuk sikap terhadap eksploitasi lingkungan (Aziz 2012).

Agama merupakan suatu sistem kepercayaan dan praktek terorganisasi, yang didasarkan pada keyakinan, yang mempostulatkan adanya makhluk-makhluk, kekuasaan, atau kekuatan supernatural yang menguasai fisik dan sosial. Realitas gejala supernatural berada diluar ranah kajian Sosiologi, karena masuk dalam ranah filosof dan teolog. Sedangkan ranah Sosiologi menelaah realitas sosial kepercayaan dan tindakan-tindakan masyarakat terkait kepercayaannya (Sanderson 2011). Tindakan-tindakan tersebut seperti aktifitas peribadatan dan perilaku yang sesuai dengan nilai-nilai Agama sebagai wujud kepercayaan terhadap akhirat.

Di seluruh Melanesia dan Polinesia, konsep agama sentral ialah konsep tentang mana. Mana bukan Dewa, melainkan suatu kekuatan supernatural yang abstrak, berada di sekeliling dan merembes ke dalam diri orang atau benda. Orang yang mempunyai nasib sangat baik dikatakan dipenuhi oleh mana, sementara mereka yang bernasib jelek dikatakan telah kehilangan mana. Dan mana itu sendiri dapat dikendalikan dan digunakan untuk memperoleh keuntungan, tetapi mana adalah suatu kekuatan impersonal, bukan Dewa ataupun Roh (Sanderson 2011). Seseorang yang dianggap oleh masyarakat mempunyai nasib sangat baik dan diyakini dipenuhi oleh mana, dapat digunakan untuk meningkatkan motivasi hidup agar dapat memiliki 
kehidupan lebih baik. Namun jika mana yang diyakini oleh masyarakat sebagai suatu anugerah seperti keberuntungan semata, relatif sulit meningkatkan motivasi, dan berpotensi menimbulkan perilaku menunggu keberuntungan yang akan menghampirinya.

Max Weber menekankan perhatian pada manusia dibentuk oleh nilai-nilai budaya sekitarnya, khususnya nilai-nilai Agama. Kemajuan ekonomi negara-negara di Eropa dan Amerika Serikat, dapat disimpulkan disebabkan oleh Etika Protestan. Disini dinyatakan seseorang sudah ditakdirkan sebelumnya masuk ke surga atau neraka. Namun orang yang bersangkutan tentu tidak mengetahuinya. Kondisi ketidak jelasan nasibnya ini, membuat mereka tidak tenang, menjadi cemas. Salah satu cara untuk mengetahui apakah mereka akan masuk surga atau neraka adalah keberhasilan kerja di dunia. Jika seseorang berhasil dalam kerja di dunia, hampir dapat dipastikan bahwa dia ditakdirkan untuk naik ke surga setelah dia mati nanti. Kalau kerjanya selalu gagal di dunia, hampir dipastikan bahwa dia akan pergi ke neraka (Budiman 1995).

Weber dalam tulisannya tentang Etika Protestan menekankan pada usaha menghindari kemalasan atau kenikmatan semaunya, dan menekankan kerajinan dalam kegiatan melaksanakan tugas dalam semua segi kehidupan, khususnya dalam pekerjaan dan kegiatan ekonomi pada umumnya. Juga menuntut untuk membatasi konsumsi, supaya uang yang ada ada itu diinvestasikan kembali dan untuk pertumbuhan modal, menuntut kesediaan untuk tunduk pada disiplin perencanaan yang sistematis untuk tujuan-tujuan dimasa mendatang, bekerja secara teratur dalam suatu pekerjaan (Johnson 1986). Dorongan keberhasilan ekonomi dalam Etika Protestan, memotivasi individu dan hal ini bersifat religius (Johnson 1986). Terlepas dari Etika Protestan yang orientasinya bersifat religius, yang bergeser kearah sekularisasi. Namun etos yang muncul dalam Etika Protestan adalah bekerja keras, disiplin, memiliki orientasi ke depan, berinvertasi dan mengindari sifat konsumtif. Ketika etos ini dimiliki oleh masyarakat protestan, berpotensi meningkatkan kesejahteraan masyarakat.

Etos dalam ajaran Agama Islam dinyatakan Muhaimin dalam Mulyadi, dalam hadist yang diceritakan bahwa "Rasulallah menegaskan kepada seorang sahabat bahwa apabila seseorang setiap waktu senantiasa beribadah di dalam Mesjid dan tidak pernah bekerja mencari nafkah untuk keluarganya dan dirinya sendiri, sehingga setiap waktu diberikan makan dan minum oleh saudaranya, maka orang yang memberi makan-minum itulah yang kelak akan menerima pahala yang sebenarnya harus diterima oleh orang yang beribadah tanpa melakukan sesuatu mata pencarian tersebut" (Mulyadi 2008). Hadis ini membahas tentang keseimbangan antara kegiatan beribadah dengan pemenuhan kebutuhan hidup (bekerja). Sama halnya dengan ungkapan seorang sahabat Nabi yang bernama Abdullah bin Amr bin al-Ash radhiyallahu $a n h u$, tentang "Bekerjalah engkau untuk kepentingan duniamu seakan engkau hidup selamanya, dan bekerjalah engkau untuk kepentingan akhiratmu seakan-akan engkau akan mati besok". Etos bekerja keras yang tidak meninggalkan ibadah, merupakan hal yang ideal dalam Islam. Weber dalam etika protestannya membahas tentang sifat konsumtif perlu dihindari, dalam Islam juga telah diatur sebelumnya. Seperti yang dijabarkan dalah hadist Nabi yang mengajarkan makan setelah lapar dan berhenti sebelum kenyang (Agus 2005). Jika etos ini disadari sepenuhnya dan dilaksanakan, maka kesejahteraan dapat tercapai dalam kehidupan masyarakat.

Membahas etos yang dimiliki masyarakat juga dilakukan oleh David McClelland, dengan melihat pertumbuhan ekonomi. Ia mengemukakan konsep the need for Achievement (n-Ach), kebutuhan atau dorongan untuk berprestasi. Orang dengan n-Ach tinggi, yang memiliki 
kebutuhan untuk berprestasi, mengalami kepuasan bukan karena mendapat imbalan dari hasil kerjanya, tetapi karena hasil kerja tersebut dianggap sangat baik. Ada kepuasaan batin tersendiri kalau dia berhasil menyelesaikan pekerjaan dengan sempurna. Jika dalam sebuah masyarakat terdapat banyak orang yang memiliki n-Ach yang tinggi, dapat diharapkan masyarakat tersebut akan menghasilkan pertumbuhan ekonomi yang tinggi (Budiman 1995). Namun $n$-Ach yang dibahas oleh McClelland ini berada pada level individu, sesuai dengan ranah kajian psikologi (Ia seorang ahli psikologi sosial).

Pemberdayaan memanfaatkan potensi yang dimiliki masyarakat juga tampak dalam program Grameen Bank (Bank Kaum Miskin) yang digagas oleh Muhammad Yunus. Dekan Fakultas Ekonomi Chittagong University Bangladesh ini, mendirikan Bank memberikan pinjaman kepada kaum miskin. Dalam program tersebut diberdayakan perempuan, yang secara kultur berada dalam posisi lemah di Desa Jobra Bangladesh (Seperti perempuan dinyatakan sebagai pembawa sengsara keluarga, tidak mampu membayar mahar, dinikahkan dalam usia relatif muda dan Adat purdah yang membuat perempuan Muslim yang telah menikah terasing dengan dunia Luar). Perempuan-perempuan ini diminta membentuk kelompok yang diberikan pinjaman bergilir, tanpa agunan atau jaminan seperti Bank pada umumnya. Kelompok ini diuji terlebih dahulu oleh pihak Grameen Bank, dengan tujuan semua anggota kelompok betanggung jawab, bersungguh-sungguh dalam membagun usaha agar keluar dari jerat kemiskinan. Setelah lulus tes, pinjaman diberikan bergilir kepada anggota kelompok dan mekanisme pembayaran pinjaman dilakukan mingguan (Yunus and Jolis 2007).

Pemberian pinjaman kepada kaum miskin ini berangkat dari asumsi bahwa semua manusia memiliki keterampilan bawaan lahir, begitu juga dengan kaum miskin. Fakta kaum miskin bertahan hidup, meskipun dengan kondisi keterbatasan merupakan bukti mereka memiliki kemampuan bertahan hidup. Mereka tidak perlu diajari cara bertahan hidup, karena sudah tahu bagaimana caranya. Kemiskinan yang mereka alami bukan karena bodoh atau malas, namun terjadi karena lembaga-lembaga finansial di Bangladesh kala itu tidak ampu memperluas basis ekonomi. Contohnya saja perempuan-perempuan yang menggantungkan hidupnya dengan membuat anyaman bambu. Sehari-hari mereka bekerja keras namun mendapatkan keuntungan yang relatif sedikit. Karena kesulitan modal, bahan baku bambu dibeli dari pedagang seharga lima taka. Setelah anyaman selesai, para perempuan kembali menjual anyaman kepada pedagang yang dihargai sebesar lima taka lima puluh poysha. Selain pinjaman juga diperoleh dari rentenir, namun dengan bunga mencapai 10\% perminggu (Yunus and Jolis 2007). Pinjaman sebesar lima taka, jika dirupiahkan sebesar, Rp 857,8, dan keuntungan yang diperoleh setelah membayar hutang pinjaman ke pedagang setara dengan 50 sen dalam rupiah. Begitu juga saat meminjam kepada rentenir, seperti sebelum bercocok tanam, seorang petani meminjam gabah, pembayaran dilakukan saat panen mencapai dua kali lebih banyak, dari gabah yang dipinjam sebelumnya. Kondisi ini membuat masyarakat terjerat dalam lingkaran kemiskinan.

Program Grameen Bank ini memanfaatkan semaksimal mungkin keterampilan yang sudah dimiliki masyarakat. Memberikan akses kredit kepada kaum miskin menjadikan mereka segera mempraktikkan keterampilan yang sudah mereka pahami. Pinjaman yang mereka peroleh selanjutkan akan menjadi alat, kunci yang membuka sejumlah kemampuan lain dan memberi mereka peluang menggali potensi dirinya (Yunus and Jolis 2007). Hal ini mampu membuat kelompok perempuan yang mendapat pinjaman, mampu keluar dari jerat kemiskinan. Etos yang ditemukan dalam masyarakat Bangladesh adalah pekerja keras, gigih dan bertanggung 
jawab terhadap hutang. Disamping etos tersebut, perempuan yang secara kultur terkungkung, diberdayakan. Saat diberdayakan muncul semangat, karena merasa dihargai dan juga memegang tanggung jawab yang besar dalam memanfaatkan pinjaman yang telah diperoleh. Hal ini mampu membawa perubahan kearah kesejahteraan, bagi perempuan-perempuan yang tergabung dalam kelompok dan mendapat bantuan pinjaman bergilir dari Grameen Bank. Meskipun dalam mengidentifikasi etos yang dimiliki masyarakat itu ditemukan oleh pihak luar (Bukan masyarakat itu sendiri), namun masyarakat miskin ini mampu menjadi pelaku utama dalam meningkatkan perekonomian mereka, bukan menjadi "budak para pemilik modal".

\section{Potensi Agama dan Adat Sebagai Basis Pemberdayaan}

Tidak ada satu suku bangsa pun yang tidak memiliki keyakinan sebagai sistem nilai dan adat sebagai normal dalam hidup dan kehidupan mereka. Sebagai sumber nilai dan norma, dapat dipastikan bahwa agama dan adat tidak mengandung nilai-nilai yang adil dan mengajarkan tentang segala hal yang baik untuk kemaslahatan hidup manusia. Oleh karenanya, Agama dan Adat kemudian menjadi etos dalam kehidupan manusia sehari-hari. Tidak terkecuali itu, masyarakat Minangkabau sebagai salah satu etnis besar di Indonesia memiliki etos agama dan adat.

Secara adat masyarakat Minangkabau merupakan salah satu masyarakat yang memiliki sistem penarikan garis keturunan secara matrilineal. Anak-anak dalam masyarakat Minangkabau relatif dekat dengan kerabat Ibu mereka. Hubungan dengan keluarga pihak Ibu (keluarga luas) sampai sekarang masih tetap langgeng dalam masyarakat. Terdapat isltilah dalam kekerabatan masyarakat Minangkabau, di antaranya seperti mamak dan kemenakan. Secara definisi kemenakan (anak-anak dari saudara perempuan) menjadi tanggung jawab Mamak. Secara umum mamak (paman) disebut sebagai saudara laki-laki ibu, baik adik maupun kakaknya. Secara khusus, mamak yakni suatu lembaga atau badan yang bertanggung jawab terhadap kelangsungan keluarga matrilineal (Sjarifoedin 2011).

Tugas utama mamak adalah memelihara, membina, memimpin kehidupan dan kebahagian jasmani serta rohani kemenakan-kemenakannya dari seluruh keluarganya. Dan Tingkah laku seseorang secara tidak langsung dikaitkan dengan kemampuan atau ketidakmampuan mamak dalam mendidik atau membina kemenakannya. Jika seseorang bertingkah laku tidak sesuai dengan nilai dan norma yang berlaku dalam masyarakat, mamaknya akan merasa malu. Begitu juga sebaliknya, mamak bangga dengan kemenakan (Sjarifoedin 2011). Etos adat dalam hubungan mamak dan kemenakan pada masyarakat Minangkabau adalah meningkatkan human capital membuat kemenakan belajar menjadi lebih baik. Secara ekonomi dalam masyarakat Minangkabau, mamak tidak akan membiarkan kemenakannya mengalami kesulitan ekonomi. Jika hal tersebut terjadi, biasanya keluarga luas, diminta membatu, karena ini diangap sebagai tanggung jawab bersama dalam masyarakat Minangkabau.

Secara agama, agama Islam merupakan adat babuhua mati dalam tatanan adat orang Minangkabau. Artinya, orang Minangkabau merupakan etnis yang wajib menganut agama. Jika tidak maka orang tersebut tidak memenuhi syarat sebagai orang Minangkabau. Dengan menjadikan Islam sebagai syarat menjadi orang Minangkabau, maka di pastikan bahwa segala nilai dan etos agama Islam telah menjadi bagian yang inheren dalam kehidupan orang Minangkabau.

Potensi Agama dan Adat yang terdapat dalam masyarakat yang telah diuraikan diatas, pada prinsipnya dapat digunakan dalam kegiatan pemberdayaan ekonomi orang minangkabau 
sebagai spirit awal, dengan tujuan penguatan ekonomi mikro. Namun dalam mempersiapkan dan menciptakan format pemberdayaan, dimana masyarakat sebagai pelaku utama ekonomi perlu mendapat pendampingan. Proses pendampingan yang dibutuhkan masyarakat sesuai dengan agama dan adat istiadat yang berlaku di Lingkungan masyarakat. Seperti dalam program Grameen Bank di Bangladesh, meskipun masyarakat miskin memiliki etos, namun dilakukan upaya peningkatan kapasitas Sumber Daya Manusia. Peningkapan kapasistas ini dilakukan dengan tujuan memahami prinsip-prinsip Grameen Bank, saat tidak lolos ujian, makan kelompok tersebut tidak akan mendapat pinjaman bergilir. Peningkatan kapasistas yang dilakukan di sini bukan dengan menjejali masyarakat miskin dengan pelatihan-pelatihan yang "menakutkan" sebelum memulai kegiatan. Dibutuhkan perencanaan dan pelaksanan kegiatan ekonomi. Masyarakat miskin diminta untuk mempersiapkan kergiatan ekonomi informal, seperti bercocok tanam, menjadi pengrajin bambu dan lain-lain. Kemudian dibutuhkan pengembangan kelembagaan ekonomi masyarakat, membekali masyarakat dengan keterampilan manajemen, teknis dan membentuk jaringan kerja.

\section{Kesimpulan}

Masyarakat memiliki potensi-potensi seperti etos Agama dan Adat yang dapat yang dapat digunakan dalam kegiatan pemberdayaan. Etos tersebut dapat ditemukan dan disadari sendiri oleh masyarakat, atau malah ditemukan oleh pihak fasilitator dalam kegiatan pemberdayaan. Etos akan sangat bermanfaat dalam kegiatan pemberdayaan dalam program penguatan ekonomi kerakyatan. Sehingga kesejahteraan yang menjadi cita-cita masyarakat miskin dapat direalisasikan.

\section{Rujukan}

Agus, Bustanuddin. 2005. Islamisasi Ilmu-Ilmu Sosial' Persepsi Dan Karya Ilmiah Ilmuwan Sosial Pro Islamisasi. Padang: Laboratorium Sosiologi FISIP Unand.

Aziz, M. 2012. Identitas Kaum Samin Pasca Kolonia; Pergulatan Negara, Agama Dan Adat

Dalam Pro-Kontra Pembangunan Semen Di Sukolilo. Kawistara.

BPS. 2014. "Laporan Bulanan; Data Sosial Ekonomi."

Budiman, Arief. 1995. Teori Pembangunan Dunia Ketiga. Jakarta: PT Gramedia Pustaka Utama.

Chamber, Robert. 1987. Pembangunan Desa Mulai Dari Belakang. Jakarta: LP3ES.

CNNIndonesia. 2016. "Ribuan Demonstran Bergerak Dari Masjid Istiqlal." $\begin{array}{llll}\text { CNNIndonesia.com. } & \text { Retrieved } & \text { November }\end{array}$ (http://www.cnnindonesia.com/nasional/20161104132913-20-170259/ribuandemonstran-bergerak-dari-masjid-istiqlal/).

Damayanti, Erlin, Mochammad Saleh Soeaidy, and Heru Ribawanto. 2014. "Strategi Capacity Building Pemerintah Desa Dalam Pengembangan Potensi Kampoeng Ekowisata Berbasis Masyarakat Lokal (Studi Di Kampoeng Ekowisata, Desa Bendosari, Kecamatan Pujon, Kabupaten Malang).” Jurnal Administrasi Publik (JAP) 2(3):464-70.

Djakfar, M. 2011. "Etos Bisnis Etika Madura Perantauan Di Kota Malang; Memahami Dialektika Agama Dengan Kearifan Lokal.” IQTISHODUNA 7(2):1-22.

Ember, Carol R. et al. 1996. Pokok-Pokok Antropologi Budaya. Jakarta: Yayasan Obor Indonesia.

Johnson, Doyle Paul. 1986. Teori Sosiologi Klasik Dan Modern. Jakarta: PT Gramedia. 
Koentjaraningrat. 1981. Pengantar Ilmu Antropologi. Jakarta: Rineka Cipta.

Mulyadi, Acep. 2008. "Islam Dan Etos Kerja: Relasi Antara Kualitas Keagamaan Dengan Etos Produktivitas Kerja Di Daerah Kawasan Industri Kabupaten Bekasi.” Turats 4(1):1-19.

Nadjib, Mochammad. 2013. "Agama, Etika Dan Etos Kerja Dalam Aktivitas Ekonomi Masyarakat Nelayan Jawa.”Jurnal Ekonomi Dan Pembangunan 21(2):137-50.

Sanderson, Stephen. 2011. Makrososiologi Sebuah Pendekatan Terhadap Realitas Sosiologi. Jakarta: Rajawali Pers.

Sherraden, Michael. 2006. Aset Untuk Orang Miskin. Jakarta: PT RajaGrafindo Persada.

Sjarifoedin, Amir Tj A. 2011. Minangkabau; Dari Dinasti Iskandar Zulkarnain Sampai Tuanku Imam Bonjol. Jakarta: PT Gria Media Prima.

Soemardjan, S. 2000. Menuju Tata Indonesia Baru. Jakarta: Gramedia.

Suherman. 2004. "Karakteristik Keluarga Miskin Dan Analisis Program Pemberdayaan Masyarakat Pedesaan: Studi Kasus Pemberdayaan Masyarakat Miskin Di Kecamatan Canduang Kabupaten Agam Propinsi Sumatera Barat."

Suyanto, Bagong. 1995. Perangkap Kemiskinan; Problem \& Strategi Pengentasannya. Surabaya: Airlangga University Press.

Yunus, Muhammad and Alan Jolis. 2007. Bank Kaum Miskin; Kisah Yunus Dan Grameen Bank Memerangi Kemiskinan. Depok: Marjin Kiri. 


\title{
A COMPARATIVE STUDY BETWEEN POLITENESS STRATEGY AND KATO NAN AMPEK ON TEACHING AND LEARNING AT ENGLISH DEPARTMENT STKIP PGRIWEST SUMATRA FACING ASEAN ECONOMIC COMMUNITY
}

\author{
Edwar Kemal \\ STKIP PGRI West Sumatra, Indonesia \\ Email : edwarkemal@yahoo.co.id
}

\begin{abstract}
Since the Indonesian Government joined for Asean Economic Community in the beginning of 2016, Indonesia has probably shown its effort to maintain its cultural heritage through many aspects and one of it is on teaching and learning. The effort is to make the cultural heritage is daily applied by the societies on every aspect of their activity. For example, the usage of kato nan ampek on teaching and learning process can make the information deliver and internalize on the lecturers and students. The purpose of the research was to find out whether the politeness strategy and kato nan ampek as the cultural heritage from West Sumatra gave significant effect in the process of teaching and learning. The method used qualitative research including observation, and interviews. Observation techniques were recording and note taking the conversation between the lecturers and students in the process of studying. Interview was conducted to lecturers and students of English Department of STKIP PGRI West Sumatra. The result shows that lecturers and students of English Department of West Sumatra have implemented progressively kato nan ampek on teaching and learning. Those types of kato nan ampek are contextually and fully implemented. The diction and utterances used can give comprehensive response from various types of hearer. In addition, because the concept of kato nan ampek has mainly been understood by lecturers and students, so that the application of politeness strategy runs well during the teaching and learning. The lecturers and student could use appropriate diction and sentence to emphasize their message and to show their politeness in speaking. It has been evidenced that kato nan ampek and politeness strategy can work together to achieve a communicative communication. Even though, kato nan ampek is a West Sumatra cultural heritage on communication, it is always implemented in the daily activity and also in Asean Economic Community era.
\end{abstract}

Keywords: Comparative Study, Politeness Strategy, Kato Nan Ampek

ISBN: 978-983-2267-95-9 


\section{Introduction}

Nowadays, Indonesia has already joined for Asean Economic Community (AEC). Joining into AEC means Indonesia and Asean Countries have a free trade. In one side, this decision can show the quality and quantity of Indonesian product, culture, resources but on the other side, it will give a serious impact for Indonesia, if Indonesia does not handle it well. It is line with Firdaus and Hakim (2013) stated on their paper that by having a big population Indonesia can play important role in AEC. Indonesian societies must be aware of AEC development in order to get beneficiary of it.

One of the serious problem is on the matter of language. Language plays important role for communicating different culture and countries. It will help the people to share their knowledge and transfer their experience. By having a good language, it will make a good relationship among others.

One of the biggest language problem is showing politeness. Using language mainly pictures out about someone's politeness. People who speak slow and nice are considered to be polite. People who speak hard and rude are considered into impolite.

Politeness is also part of culture. There are many cultures in Indonesia and absolutely they also have many languages. Each of the culture has own way to speak polite or impolite. Perhaps, in one culture, the way of communication could be polite, while on the other culture, the used way may be impolite. It is because each of the culture has own standard of politeness.

Talking about English, it has own standard about politeness. In an English speaking country culture, sometimes, speaking by using modal shows that it is a polite way of speaking. On the other side, speaking straightly to the point shows a polite speaking. It is generally called as politeness strategy.

Minangkabau, one of the cultures of Indonesia, also has own standard to show the politeness in communication. It is well-known as kato nan ampek. Kato nan ampek is a way of communicating from Minangkabaunese to respect or to interact among others. If one of the Minangkabaunese does not know how to use kato nan ampek, he/she is considered impolite.

STKIP PGRI West Sumatra is one of the private universities in West Sumatra. This university has many students coming from different status and even culture. There are three languages at least are used by students to communicate to other students and their lecturers. They are Indonesian Language, Local Language and English. Sometimes, lecturer and student mix about the language used for communicating.

This research has some functions i.e. and then to analyze how the lecturers and students show their politeness in speaking through politeness strategy and kato nan ampek and to compare between the politeness strategy and kato nan ampek used by lecturers-students during teaching and learning in English department of STKIP PGRI West Sumatra.

\section{Review Related Literature}

This research is one of the pragmatics studies. This research elaborates some theories in order to analyze the data and get the research findings. The first theory is a theory about politeness strategy proposed by Brown and Levinson in Pariera (2006) who divided the politeness strategy into bald on record, positive politeness, negative politeness, and off record. Bald on record means that the speaker doesn't minimize threats to the hearer face. Positive politeness tries to apply the closeness and solidarity. It makes the hearer feels comfortable. 
Negative politeness means giving a distance to the hearer and do not disturb one and another area. Off record means that saying something but it is indirectly to the point.

Second theory is theory about kato nan ampek. It is divided into four where kato mandaki, mandata, malereang dan manurun. Kato mandaki means that the speaker is talking to a person older than the speaker itself. Kato mandata means that speaker speaks to the hearer with the same ages. Kato malereang means that speaker is talking to a respected person.kato manurun means speaker is talking to younger person.

Context plays significance role in analyzing the politeness of an utterance. If someone, doesnt understand about the context of situation, he or she will have a wrong interpretation. Context also helps the hearer to make a good utterance. Hymes in Johnstone and Marcellino ( 2010) stated that context are derived from the word of SPEAKING. They are as setting, scene, participants, ends, act sequences, keys, instrumentalies, norms, genres.

\section{Research Design}

This research is a descriptive research where it means that the research explains about the existing phenomena and as it is. The method of data collection used non participant observation. It means that the researcher did not involve in creating the data. The technique used were video, taking note and interview. Method of analysis used pragmatic identity method and method of presentation was using sentences. Source of the data was all of the lecturerstudent utterances during teaching and learning. The data are the utterances related to the politeness strategy and kato nan ampek.

\section{Discussion and Research Finding}

\section{IV.1. Discussion}

After collecting the data from video, the research had 10 data related to the politeness strategy and kato nan ampek as found on the conversation between lecturers-students during on teaching and learning. Here are some examples of the data.

\section{Bald on Record}

\section{Datum 1}

(Context: Lecturer is discussing a material of the lesson. Students are reading the material and trying to comprehend it)

L : What did then happen in the party?

$\mathbf{S}$ : (The students are reading the material and keeping silent)

L : Fika!

$\mathbf{S}$ : The defintion of the word is

This conversation happens in a classroom. At the time the teacher is giving a material to the students and he wants the students to understand about it. The data is included into bald on record. It is because the speaker does not try to minimize the hearer's face. He calls the name right away. In terms of kato nan ampek, this data belongs to the kato manurun. It can be seen the lecturer is feeling okay to call the student's name. It does not have a problem he did so because the lecturer is older than the students. 


\section{Positive Politeness}

\section{Datum 2}

(Context: The class has been started since half an hour ago. The lecturer is a discipline person. There is one student that comes late and wants to get in to have learning)

S : Excuse me, Sir. I am sorry for the late sir.

$\mathrm{L} \quad$ : Andi. Come here. don't be late next time okay? (smile)

$\mathrm{S} \quad$ : Okay sir (smile)

On this conversation, it can be seen that the student was coming quite late to the class. The student was a student who repeats the same subject. The lecturer had already known with the student because he thought him before. Based on the politeness strategy, it can be categorized into positive politeness. It is because the speaker tries to show his closeness and solidarity. $\mathrm{He}$ does not want to loose the face of the hearer. In terms of the kato nan ampek, this data belongs to kato manurun. It is because the speaker considers that the student is like his brother. He has a brother who has the same age with the student. It is known after conducting the interview.

\section{Negative Politeness}

Datum 3

(Context : The teaching and learning is going on but suddenly, one of the student comes to the lecturer's table.

S : Sir. Actually I want to study but my stomach is pain. May I go home?

L : Okay. You may go home.

On this conversation, the data is grouped into negative politeness. It is because the speaker tries to make a distance with the hearer by saying Sir. She respected the hearer. Though she respects him but the speaker also wants to get what she wants. So, she does not disturb him anyway because she respects him first and tell her problem. In terms of kato nan ampek, the data belongs to kato mandaki. It is stated that she calls the hearer by saying Sir. It is a honored calling for an older person. She respects him by saying that calling.

\section{VI.II Research Finding}

After analyzing the data, it can be seen that most of the data are grouped into bald on record, positive politeness and negative politeness in relation to the politeness strategy theory. Meanwhile, in relation to the kato nan ampek, the data are categorized into kato mandaki and kato manurun. It is clear to be seen that lecturer will use kato manurun to his students and his students will use kato mandaki to speak to him.

It also can be seen on the following tables:

Table 1. Politeness Strategy

\begin{tabular}{|r|c|c|c|c|c|}
\hline N o & Datum & BOR & PP & NP & OFR \\
\hline 1 & 1 & v & & & \\
\hline 2 & 2 & & v & & \\
\hline 3 & 3 & & & V & \\
\hline 4 & 4 & & v & & \\
\hline
\end{tabular}


BOR : Bald On Record

\begin{tabular}{|l|l|l|l|l|l|}
\hline 5 & 5 & & $\mathrm{v}$ & & \\
\hline 6 & 6 & & & $\mathrm{~V}$ & \\
\hline 7 & 7 & $\mathrm{~V}$ & & & \\
\hline 8 & 8 & & $\mathrm{v}$ & & \\
\hline 9 & 9 & & & $\mathrm{~V}$ & \\
\hline 10 & 10 & $\mathrm{v}$ & & & \\
\hline \multicolumn{2}{|l|}{ Total } & $\mathbf{3}$ & $\mathbf{4}$ & $\mathbf{3}$ & 0 \\
\hline
\end{tabular}

$P P \quad:$ Positive Politeness

NP : Negative Politeness

OFR : Off Record

On this table, it can be seen that positive politeness strategy is the highest occurrence as found on teaching and learning in STKIP PGRI West Sumatra. There are some information raising why this type of this politeness strategy mostly applied. First is STKIP PGRI West Sumatra is teaching and education - based college. Second, this college also applies soft skill as the main component to behave in the college environment. Those factors really influence the politeness strategy.

Table 2. Kato Nan Ampek

\begin{tabular}{|l|l|l|l|l|l|}
\hline N o & Datum & KMDK & KMRN & KMDT & KMLR \\
\hline 1 & 1 & & $\mathrm{~V}$ & & \\
\hline 2 & 2 & & $\mathrm{~V}$ & & \\
\hline 3 & 3 & $\mathrm{v}$ & & & \\
\hline 4 & 4 & & $\mathrm{~V}$ & & \\
\hline 5 & 5 & & $\mathrm{~V}$ & & \\
\hline 6 & 6 & $\mathrm{~V}$ & & & \\
\hline 7 & 7 & $\mathrm{~V}$ & & & \\
\hline 8 & 8 & & $\mathrm{~V}$ & & \\
\hline 9 & 9 & & $\mathrm{~V}$ & & \\
\hline 10 & 10 & $\mathrm{~V}$ & & & \\
\hline total & & $\mathbf{4}$ & $\mathbf{6}$ & $\mathbf{0}$ & $\mathbf{0}$ \\
\hline
\end{tabular}

$\begin{array}{ll}\text { KMDK } & : \text { Kato Mandaki } \\ \text { KMRN } & : \text { Kato Manurun } \\ \text { KMDT } & \text { : Kato Mandata } \\ \text { KMLR } & : \text { Kato Malereng }\end{array}$

On the table, it can be seen that kato manurun is the highest occurrence on teaching and learning at STKIP PGRI West Sumatra. There is a reason why this type mostly happen. It is 
because the lecturers plays a big role in determining the teaching and learning. Lecturer is still considered the center of all activities on the class.

\section{Conclusion}

Based on the data analysis and research finding, it can be concluded that politeness strategy and kato nan ampek work side by side on communication during teaching and learning. Kato nan ampek as the cultural heritage of West Sumatra is still applied both lecturers and students on teaching and learning. The culture will not be seriously affected by the coming of Asean Economic Community. Both lecturers and students can implement both of this politeness.

\section{References}

Firadus, Ahmad Yarist and Hakim, Muhammad Andi. 2013. Penerapan "Accelleration to improve the Quality of Human Resources" dengan Pengetahuan, Pengembangan dan Persaingan sebagai Langkah dalam Mengoptimalkan Daya Saing Indonesia di MEA 2015. Economics Development Analysis Journal 2 (2).

Johnstone, Barbara and Marcellino, William. 2010. Dell Hymes and Ethnography of Communication. Carnegie Mellon University: Research Showcase.

Pariera, Katrina. 2006. The Use of Politeness Strategy in Email Discussion about Taboo. PSU Mcnair Scholars Online Journal. Article 29.

Wahid, Syafrudin. 2014. Komunikasi pada Lembaga Pendidikan Non Formal. Jurnal Ilmu Pendidikan. Jilid 20 nomor 1 Juni 2014. 
